Resumen por el autor, Albert Kuntz.

Escuela Médica de la Universidad de Saint Louis.

El desarrollo del sistema nervioso simpático en el hombre.

En el hombre, el simpático guarda con el sistema nervioso cerebroespinal la misma relación genética que en los vertebrados inferiores. Las células que producen las neuronas del simpático derivan de los ganglios cerebro-espinales y del tubo neural. Las células que entran a formar parte de la substancia primordial de los troncos del simpático y plexos prevertebrales avanzan periféricamente a lo largo de las raices dorsales y ventrales de los nervios espinales. Las que dan lugar a los ganglios de los plexos del simpático en el vago avanzan periféricamente a lo largo de los nervios vagos. Los grandes ganglios del simpático de la región craneal, esto es, los ganglios ciliares, esfenopalatinos, óticos y submaxilares, reciben células que avanzan periféricamente a lo largo de los nervios que transportan mas tarde fibras preganglionares a cada ganglio de los mencionados, y a lo largo de las divisiones respectivas del nervio trigemino.

Translation by José F. Nonidez

Cornell Medical College, New York 
ACTHOR'S ABSTRKCT OF THBS PAPER ISSDED

BY THE BIBLIOGRAPHIC SERVICE, JULY 12

\title{
THE DEVELOPMENT OF THE SYMPATHETIC NERVOUS SYSTEM IN MAN
}

\author{
ALBERT KUNTZ \\ Department of Anatomy, Saint Louis University School of Medicine \\ THIRTY-ONE FIGERES \\ CONTENTS
}

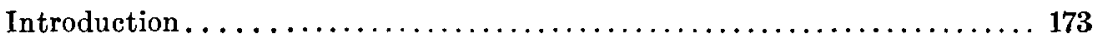

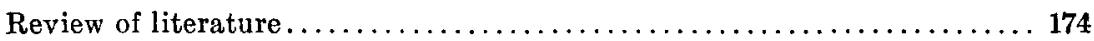

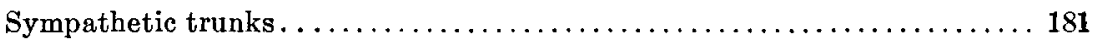

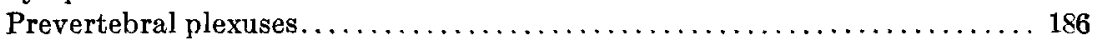

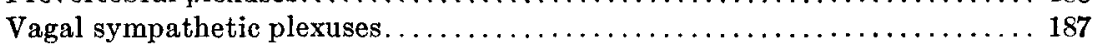

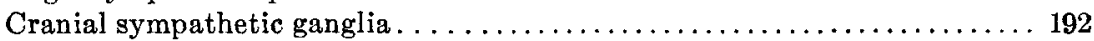

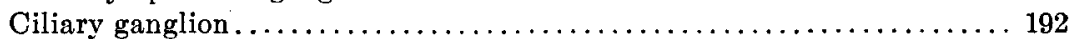

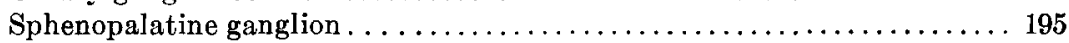

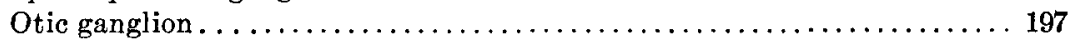

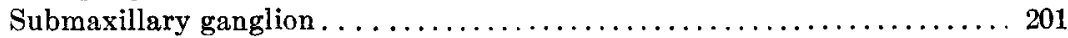

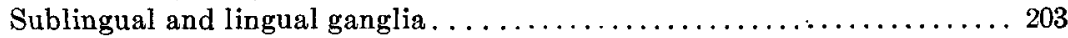

Sources of the sympathetic neurones.......................... 204

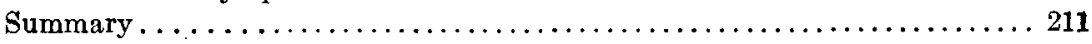

\section{INTRODUCTION}

The development of the sympathetic nervous system has long been one of the perennial problems in vertebrate embryology. The literature on this subject, representing the work of a large number of investigators, has become voluminous, but reveals no general agreement regarding some of the fundamental aspects of the problem. The majority of the more recent investigators agree in general regarding certain phases of the problem, but disagree regarding others. The major portion of the fundamental work recorded is based on embryos of the lower vertebrates. Some important contributions are based on embryos of a variety of mammals, but relatively few. of the observations recorded were made on human embryos. 
The present writer published the results of his earlier studies on the development of the sympathetic nervous system in a series of papers ('09-'14). The conclusions drawn from these studies regarding certain fundamental aspects of the problem, especially with reference to certain portions of the sympathetic system, differ widely from those of the earlier investigators. Some of these conclusions have been substantiated by the work of later investigators; some have suffered adverse criticism. More mature study on the part of the writer has fortified his confidence in the more fundamental conclusions, but has also revealed errors of major and minor importance both in observation and interpretation. In view of the present status of the problem, it has seemed desirable to undertake the present investigation in order to correct certain errors referred to above, to treat more adequately certain details of the problem which have not been adequately studied hitherto, and to secure more accurate and more extensive knowledge regarding the development of the sympathetic nervous system in the human species.

The observations recorded in this paper, except as otherwise indicated, were made on human embryos included in the Carnegie Embryological Collection. It is a real pleasure to express my indebtedness to Dr. G. L. Streeter for placing this collection at my disposal, for the opportunity of working in his laboratories, and for the technical assistance of members of his staff in the preparation of microphotographs.

\section{REVIEW OF LITERATURE}

The literature bearing on the development of the sympathetic ${ }^{1}$ nervous system in vertebrates has been reviewed more or less fully by nearly all of the many investigators who have worked in this field. It was reviewed also by the present writer in 1910.

${ }^{1}$ The writer appreciates the need of a terminology applied to this division of the nervous system which could be accepted alike by anatomists and physiologists. However, inasmuch as the term 'sympathetic' was used in its broad sense by the writer in his earlier papers, as well as by the majority of the more recent investigators in this field, it seems advisable to use it in the same sense in this paper. 
For the purposes of the present paper it will suffice to set forth the views which were prevalent at that time and to consider somewhat more fully the several papers which have appeared during the past decade.

While the great majority of the investigators in this field have agreed that the sympathetic is derived from the cerebrospinal nervous system, a few, of whom Camus ('12) is the most recent, have attributed to this division of the nervous system a mesodermal origin. Inasmuch as no purpose can be served at this time by discussing a theory which is so obviously erroneous, the work of the latter authors will not be considered further in this paper.

There has always been a divergence of opinion among the advocates of the ectodermal origin of the sympathetic nervous system regarding the exact sources and the histogenesis of the sympathetic cells. Ever since the genetic relationship of the sympathetic to the cerebrospinal nervous system was clearly pointed out by Balfour ('77), the majority of the investigators derived the cells which give rise to the primordia of the entire sympathetic nervous system from the cerebrospinal ganglia or the neural crest; however, there has been no general agreement regarding the method by which these cells are displaced from the cerebrospinal ganglia into the sympathetic primordia. According to the theory first set forth by Ónodi ('86), cells are forced to advance peripherally from the distal ends of the spinal ganglia by the pressure which is exerted by the newly formed elements back of them. These cells become displaced toward the dorsolateral aspects of the aorta and give rise to the primordia of the sympathetic trunks. His, Jr. ('91), introduced the principle of the active migration of the cells which give rise to the sympathetic primordia along the paths of the spinal nerves and the communicating rami. Some of the more recent investigators are of the opinion that migration of cells from the spinal ganglia occurs earlier than was observed by His, Jr., and that the majority of the cells which enter the primordia of the sympathetic trunks migrate through the mesenchymal tissue or in advance of the growing fibers of the spinal nerves and the com- 
municating rami rather than along the compact fibrous paths of the latter.

The differences of opinion above set forth regarding the method by which cells which take part in the development of the sympathetic nervous system are displaced peripherally may be accounted for in part by fundamental differences in the morphogenesis of the sympathetic trunks in the several classes of vertebrates. The primordia of the sympathetic trunks arise in the Elasmobranchii as ganglionic enlargements on the spinal nerves (Balfour, '77; van Wijhe, '89; Hoffmann, '99). They arise in the Amphibia as aggregates of cells lying along the dorsolateral aspects of the aorta after fibers are present in the communicating rami (Hoffmann, '02; Neumayer, '06). In birds the primary sympathetic trunks arise as a pair of cell-columns lying along the dorsolateral aspects of the aorta. These early give way to the secondary sympathetic trunks, the primordia of which arise as aggregates of cells just mesial to the ventral roots of the spinal nerves (His, Jr., '97). In mammals the primordia of the sympathetic trunks arise as cell-columns lying along the dorsolateral aspects of the aorta (His, '90; Kohn, '05, '07). With these observed differences in the morphogenesis of the sympathetic trunks in mind, it is apparent that the theory advanced by Ónodi was based on his findings in the Elasmobranchii, while the theory of the active migration of cells into the sympathetic primordia was based primarily on observations made on embryos of birds and mammals.

A few investigators, notably Kohn ('05, '07) and Neumayer ('06), do not admit that active cell migration occurs; but account for the aggregates of cells which constitute the primordia of the sympathetic trunks by the proliferation of elements which are differentiated in situ in the spinal nerves. Obviously, the views of these authors are influenced by their allegiance to the theory of local differentiation and the multicellular nature of nerve-fibers.

Froriep, who like a number of investigators before him, had previously observed that cells of medullary origin advance peripherally along the ventral roots of the spinal nerves, in 1907 presented evidence which indicates that some of these cells enter 
the primordia of the sympathetic trunks and expressed the opinion that it is essentially these cells which give rise to the neurones in the sympathetic nervous system. Cajal ('08) expressed essentially the same opinion. His observations on embryos of the chick led him to the conclusion that the sympathetic cells are true motor cells which are derived from the spinal cord.

The work of Froriep was attacked most vigorously by Held ('09) and Marcus ('09), both of whom adhere to the older theory, according to which the cerebrospinal ganglia (or the neural crest) constitute the sole source of the cells which enter the primordia of the sympathetic nervous system. Perhaps no one among the more recent investigators would concur in the opinion of Froriep and Cajal that all sympathetic neurones are derived from cells of medullary origin which advance peripherally along the fibers of the motor nerve roots; however, their conclusion that cells of this type enter the primordia of the sympathetic trunks has been amply confirmed.

The older investigators studied primarily the development of the sympathetic trunks and the sympathetic plexuses along the abdominal aorta. No extensive observations on the development of the sympathetic plexuses related to the vagi, viz., the pulmonary, the cardiac, and the enteric plexuses, were recorded prior to the publication of the earlier work of the present writer in 1909 and 1910; however, it was generally assumed that the cells which give rise to the neurones in these plexuses are derived from the primordia of the sympathetic trunks. The earlier work of Abel ('10) is in full accord with this general assumption. She derived the enteric plexuses in the chick from cells which migrate "from the spinal cord and the intervertebral ganglia downward through the mesentery to the gut." . The later work of Abel will be referred to presently.

Observations on the development of the cranial portion of the sympathetic nervous system, except the ciliary ganglion, which were published prior to the beginning of the past decade are fragmentary and incomplete. The scattered literature bearing on the development of the ciliary ganglion was reviewed by Carpenter ('06). This review reveals a wide difference of opinion 
regarding the exact sources and the histogenesis of this ganglion. According to Hoffmann ('85), Ewart ('90), and Chiarugi ('94, '97), it arises from cells which advance from the semilunar ganglion into the oculomotor nerve either directly or by way of the ophthalmic division of the trigeminal nerve. Dohrn ('91) expressed the opinion that in the Elasmobranchii the ciliary ganglion arises from cells which migrate from the midbrain along the path of the oculomotor nerve. Béraneck ('84), Reuter ('97), and Rex ('00) also derived this ganglion from cells present in the oculomotor nerve, but did not determine the exact sources of these cells. According to Carpenter ('06), the ciliary ganglion arises in the chick from cells which migrate from the wall of the midbrain along the oculomotor nerve, but later receives some cells which advance peripherally from the semilunar ganglion along the ophthalmic nerve. The available evidence bearing on the development of the other cranial sympathetic ganglia seemed to favor the assumption that the sphenopalatine, the otic, and the submaxillary are derived exclusively from the semilunar ganglion.

Such in brief was the status of the problem when the present writer initiated a series of studies on the development of the sympathetic nervous system in embryos of types of the several classes of vertebrates. The results of these studies which were published in a series of papers ('09-'14) indicate that the sympathetic bears essentially the same genetic relationship to the cerebrospinal nervous system throughout the vertebrate series. The sympathetic trunks, though differing somewhat in their morphogenesis in the several classes of vertebrates, arise from cells of cerebrospinal origin which advance peripherally both along the dorsal and ventral roots of the spinal nerves. The cells which give rise to the ganglia of the prevertebral plexuses are derived from the same sources. The sympathetic plexuses related to the vagi, viz., the pulmonary, the cardiac, and the enteric plexuses, except in the aboral portions of the digestive tube, are not genetically related to the sympathetic trunks, but arise from cells of cerebrospinal origin which advance peripherally along the paths of the vagi. This finding was corroborated by the work 
of Abel ('12) on embryos of the chick and more recently by that of Stewart ('20) on embryos of the rat. The cranial sympathetic ganglia arise in a manner essentially analogous to that in which the sympathetic trunks arise. The ciliary ganglion arises in intimate association with the oculomotor nerve in all classes of vertebrates. The writer's observations on this ganglion agree with those of Carpenter ('06) which indicate that it arises from cells which advance peripherally both along the oculomotor and ophthalmic nerves. The conditions found to obtain in embryos of the lower vertebrates with respect to the other cranial sympathetic ganglia need not be set forth at this time. In embryos of the turtle and the chick the sphenopalatine ganglion was found to arise in the path of the great superficial petrosal nerve and to become connected early with the maxillary nerve. It receives cells which advance peripherally both along the great superficial petrosal and the maxillary nerves. In embryos of the pig the relationship of the primordium of this ganglion to the great superficial petrosal nerve was less obvious. While it was recognized that cells might enter this ganglion along the great superficial petrosal nerve, it was erroneously concluded that the sphenopalatine ganglion arises, in embryos of the pig, primarily from cells which advance peripherally from the semilunar ganglion. The writer's observations on the development of the otic ganglion led him to conclude that in embryos of the chick this ganglion arises primarily from cells which advance from the primordium of the superior cervical ganglion along the internal carotid nerve, while in embryos of the pig it arises almost exclusively from cells which advance peripherally along the mandibular division of the trigeminal nerve. In the light of the present investigation, these conclusions are obviously erroneous. They will be referred to again in a later section of this paper. The submaxillary ganglion is derived primarily from cells which advance from the semilunar ganglion along the path of the lingual division of the mandibular nerve.

In a recent series of papers Ganfini ('11-'18) has published extensive and detailed observations on the development of the sympathetic nervous system in embryos of types of all the classes 
of vertebrates above the Elasmobranchii. According to his observations, the ganglia of the sympathetic trunks arise from 'neurocytes' which advance peripherally both along the dorsal and ventral roots of the spinal nerves. From the primordia of the sympathetic trunks cells advance farther ventrally and give rise to the ganglia in the plexuses along the abdominal aorta. The enteric plexuses, according to Ganfini, arise from cells derived from the primordia of the sympathetic trunks which advance farther ventrally and enter the walls of the digestive tube. He recognizes cells which advance distally along the vagi and enter the pulmonary, the cardiac, and the oesophageal plexuses, but he seems to be of the opinion that these cells migrate from the superior cervical ganglia. He also recognizes the double origin of the ciliary ganglion in the lower vertebrates. While he finds the contribution to this ganglion of cells which advance distally along the oculomotor nerve less obvious in mammalian embryos than in embryos of lower vertebrates, he does not exclude it even in embryos of this class of vertebrates; consequently, his conclusions regarding the development of the ciliary ganglion are in essential accord with those of Carpenter and the present writer. The sphenopalatine, the otic, and the submaxillary ganglia, according to Ganfini, are derived primarily from the semilunar ganglion.

The most recent work on the development of the cranial sympathetic ganglia is that of Stewart ('20) which is based on embryos of the rat. With respect to all these ganglia, except the ciliary, Stewart has adhered strictly to the theory that the cells which give rise to each respectively advance peripherally along the nerve, or nerves, which, in the adult, carry its preganglionic fibers. His findings will be considered further in a later section of this paper.

The scattered observations on the development of the sympathetic nervous system in human embryos which were published prior to 1910 were reviewed by Streeter ('12), who also recorded his observations. Further studies based on human embryos were published by Broman (11). The work both of Streeter and Broman is in general accord with that of the earlier investi- 
gators, according to whom the primordia of the entire sympathetic nervous system are derived from the cerebrospinal ganglia by the peripheral displacement of cells of neural-crest origin.

\section{SYMPATHETIC TRUNKS}

The primordia of the sympathetic trunks arise in human embryos about $5 \mathrm{~mm}$. in length as small groups of cells lying along the dorsolateral aspects of the aorta in the lower thoracic and upper abdominal regions. These cells may be recognized among the mesenchymal cells by the slightly larger size and more intense staining reaction of their nuclei. In embryos $6 \mathrm{~mm}$. in length (nos. 676, 242) 2 $^{2}$ the sympathetic primordia are present from the lower cervical to the sacral region. By reason of the strong curvature of the embryo at this stage, the aggregates of cells constituting the primordia of the segmental ganglia lie in such close proximity with each other that the entire primordium of the sympathetic trunk appears as a continuous column of loosely aggregated cells. This condition obtains until the embryos have reached a length of 9 to $10 \mathrm{~mm}$. and the primordia of the sympathetic trunks are present from the upper cervical to the sacral region. Longitudinal fibers may not be observed in the primordia of the sympathetic trunks until the segmental character of the latter has become apparent. In the upper thoracic and cervical regions the sympathetic primordia arise along the dorsal aspects of the descending aortae. Doubtless the position of these primordia is in part determined by the position of the great arterial trunks. Inasmuch as the paired descending aortae lie at an appreciable distance from the median plane and converge toward the unpaired dorsal aorta, the primordia of the sympathetic trunks lie farther from the median plane in the cervical and upper thoracic than in the abdominal region.

When the primordia of the sympathetic trunks first appear, the cells are very loosely aggregated and the fibers of the com-

\footnotetext{
${ }^{2}$ Numbers inserted in this manner are the serial numbers of human embryos in the Carnegie Embryological Collection.
} 
municating rami cannot be traced among them. A little later the fibrous communicating rami may be traced into these cell aggregates (figs. 1 and 13). In the abdominal region some of these fibers tend ventrally along the lateral aspects of the aorta toward the regions in which the prevertebral plexuses arise (fig. 2). Cells of cerebrospinal origin are present, during early development, both in the dorsal and ventral roots of the spinal nerves as well as in the mixed nerve trunks and the paths of the communicating rami. Migrant cells of medullary origin associated with the fibers of the ventral root of a spinal nerve in an embryo $9 \mathrm{~mm}$. in length are illustrated in figures $3 \mathrm{~A}$ and 14 . Such cells are present in the motor nerve roots both within and without the external limiting membrane and occasionally, as illustrated microphotographically in figure 14, $\mathrm{cvr}$, an individual cell may be observed in the process of passing through this membrane. Beyond the junction of the dorsal and ventral roots of the spinal nerves the cells of medullary and ganglionic origin cannot be distinguished from each other. As these cells advance peripherally, some of them enter the sympathetic primordia to give rise to sympathetic neurones.

Some of the more recent investigators, including the present writer, have expressed the opinion that many of the cells which enter the sympathetic primordia migrate peripherally in advance of the growing nerve fibers. The early migration of sympathetic cells in human embryos was emphasized by Streeter ('12), who expressed the opinion that the majority of the cells which enter the primordia of the sympathetic trunks advance toward the aorta before fibers are present in the communicating rami; consequently, he described the early communicating rami as cellular strands. Ganfini ('17) ${ }^{3}$ also described cellular communicating rami in early mammalian embryos (guinea-pig and pig) which later give way to the fibrous rami. As is well known, the distal portions of growing nerve fibers are not brought out clearly by the ordinary staining processes; however, as illustrated in figures 1 and 13 , fibers are present in the communicating rami relatively

${ }^{3} \mathrm{I}$ am indebted to my student, Mr. José Zozaya, for reading Ganfini's and other Italian papers. 


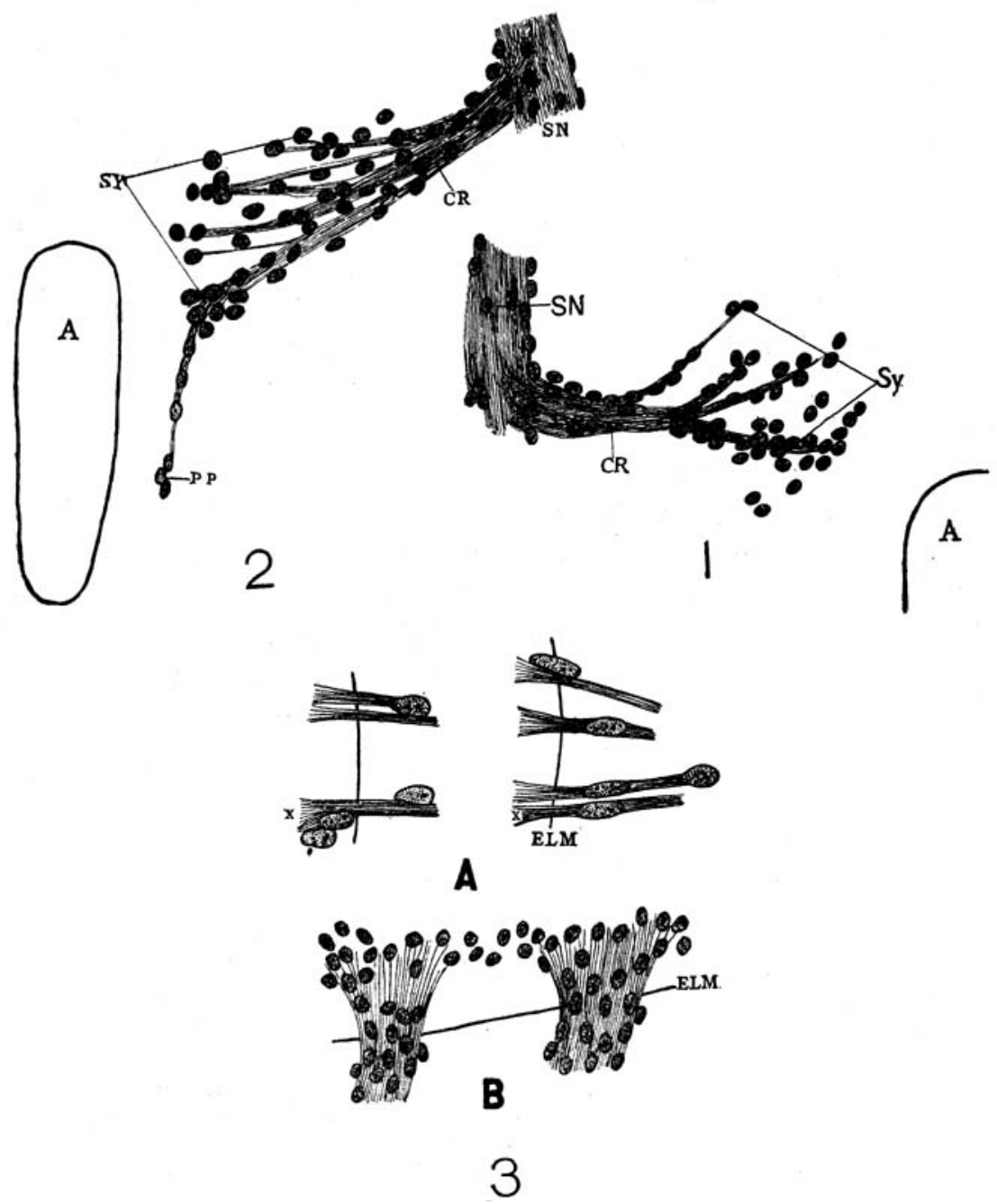

Fig. 1 Human embryo, $7 \mathrm{~mm}$. in length, 617-13-1-3×155.4 Transverse section through lower thoracic region showing spinal nerve and sympathetic trunk. To be compared with figure 13. A, aorta; $C R$, communicating ramus; $S N$, spinal nerve; $S y$, sympathetic trunk.

Fig. 2 Human embryo, $6 \mathrm{~mm}$. in length, 676-11-4-4. Transverse section through upper abdominal region showing spinal nerve and sympathetic trunk. $A$, aorta; $C R$, communicating ramus; $P P$, cells advancing into prevertebral plexus; $S N$, spinal nerve; $S Y$, sympathetic trunk.

Fig. 3 A. Human embryo, $9 \mathrm{~mm}$. in length, $721-12-3-4$ and 5. Fiberbundles with accompanying cells in ventral root of spinal nerve. B. Human embryo $11.5 \mathrm{~mm}$. in length, $544-5-3-2$. Vagus rootlets showing fibers with accompanying migrant cells. $E L M$, external limiting membrane; $X$, the same fiber bundle in successive sections.

${ }^{4}$ Numbers used in this manner indicate serial number of embryo, serial number of slide, row of sections on slide, number of section in row, and magnification. 
early. Nevertheless, the writer is still of the opinion that the earliest cells enter the primordia of the sympathetic trunks in advance of the growing fibers.

That a fibrous tract is not essential for the peripheral migration of cells of cerebrospinal origin is obvious in embryos of the turtle in which, as observed by the writer in an earlier paper ('11), many of the cells which enter the primordia of the sympathetic trunks advance from the spinal nerves, not along the paths of the communicating rami, but directly through the mesenchyme. This observation was corroborated by Ganfini ('14) in embryos of other reptilian types. Obviously, if cells entering the sympathetic primordia could not be displaced in advance of the growing nerve fibers or in the absence of a fibrous path, the cells constituting the primordia of the sympathetic trunks would not occur as widely scattered in the mesenchyme as is the case even in human embryos.

The peripheral migration of cells of cerebrospinal origin into the primordia of the sympathetic trunks continues actively in human embryos for some time after the communicating rami have become fibrous. During the same interval the number of cells in these primordia is materially increased by local cell division. Human embryos $10 \mathrm{~mm}$. and over in length afford little evidence that migration of cells along the communicating rami continues after a length of $12 \mathrm{~mm}$. has been attained.

Relatively few careful observations on the development of the cervical portions of the sympathetic trunks have been recorded. All who made special mention of these structures in embryos of the higher vertebrates noted that their primordia arise later than the primordia of the thoracic portions of the sympathetic trunks. They also noted that there occurs a gradual extension of the cell-columns which constitute the primordia of the sympathetic trunks from the upper thoracic region cephalad until the level of the first cervical nerve is reached. Nevertheless, the general impression that each pair of cervical spinal nerves makes its contribution of cells to these primordia seems to prevail. Ganfini ('17) maintains that in early embryos both of the guinea-pig and the pig cellular communicating rami extend from 
the cervical spinal nerves toward the primordia of the sympathetic trunks and that 'neurocytes' advance into the latter along these cellular rami. These cellular rami disappear early, according to Ganfini, after which there are no connections between the cervical spinal nerves, except the last, and the sympathetic trunks until the fibers which constitute the gray communicating rami are present. Although the writer has given especial attention to the development of the cervical portion of the sympathetic trunks, both in human embryos and in embryos of the pig, he was unable to substantiate this observation of Ganfini, nor could he obtain any evidence that the cervical spinal nerves with which no white communicating rami are associated play any part in the development of the sympathetic trunks. The writer's observations indicate that the primordia of the sympathetic trunks grow cephalad from the lower cervical region both by the displacement of cells along the dorsal aspect of the descending aortae and by local cell division. In this connection Streeter's observation that in the cervical and upper thoracic regions the primordia of the sympathetic trunks are not segmental, but "the cells remain massed in larger clumps, and these result in ganglia corresponding to from two to five segments," is not without interest. The cervical portions of the primordia of the sympathetic trunks are indeed continuous cell-columns until the condensations which result in the ganglia characteristic of the cervical sympathetic trunks are initiated.

In embryos $10 \mathrm{~mm}$. in length the cell-masses constituting the primordia of the sympathetic trunks have become larger and more compact (fig. 16, sy). Although some of the cells still remain somewhat scattered, the segmental character of the sympathetic trunks is becoming more apparent and longitudinal fibers are present; however, the rami connecting the adjacent ganglia are nowhere free from sympathetic cells. As development advances the curvature of the embryo becomes less marked, and the ganglia of the sympathetic trunks become more widely separated. These ganglia also become more compact and more sharply delimited. In sagittal sections of an embryo $15 \mathrm{~mm}$. in length (no. 390) the segmental character of the sympathetic trunks is well marked 
throughout the thoracic and abdominal regions. The condensations which result in three ganglionic masses in the cervical region also have become apparent. Fibers may now be traced from the upper ends of the superior cervical ganglia cephalad along the internal carotid arteries. These ganglia are not sharply limited at their upper extremities, and apparently some cells advance along the fibers of the internal carotid nerves. The majority of these cells probably become incorporated in the plexuses on the internal carotid arteries. In embryos 20 to 22 $\mathrm{mm}$. in length the sympathetic trunks have assumed a relationship to the vertebral condensations. The ganglia are quite sharply delimited and the fibrous rami between them are relatively free from cells.

\section{PREVERTEBRAL PLEXUSES}

In the upper abdominal region of an embryo $6 \mathrm{~mm}$. in length (no. 676) a few cells may be traced from the primordia of the sympathetic trunks ventrally along the lateral aspects of the aorta. In a few segments of this embryo and in embryos which are somewhat farther advanced some of the fibers of the communicating rami tend ventrally along the paths of these cells (fig. 2). In embryos which are somewhat older, fibers which arise from cells in the primordia of the sympathetic trunks also grow ventrally into the region in which the ganglia of the prevertebral plexuses arise. During this interval cells become separated from the ventral borders of the primordia of the sympathetic trunks throughout the abdominal region and advance ventrally to give rise to the ganglia of the prevertebral plexuses. At the same time other cells which are associated with those fibers of the communicating rami which turn ventrally without passing through the ganglionic masses at the dorsolateral aspects of the aorta advance into the prevertebral plexuses more or less directly from the spinal nerves. In embryos 9 to $10 \mathrm{~mm}$. in length the aggregates of sympathetic cells lying along the ventral and ventrolateral aspects of the abdominal aorta have assumed considerable size. In an embryo $10.1 \mathrm{~mm}$. in length (no. 623) these 
cell-masses are very conspicuous all along the abdominal aorta (figs. 16 and $17, p v$ ). At this stage some cells have already become displaced laterally from these masses toward the primordia of the adrenal glands and along the renal arteries. The greatest accumulation of sympathetic cells ventral to the abdominal aorta occurs about the coeliac artery. The several plexuses which arise along the abdominal aorta are not yet clearly delimited. Neither can fibers be traced from these plexuses into the mesentery. As development advances these several plexuses become more clearly differentiated, while the ganglionic masses become relatively larger and more compact. From these ganglionic masses cells may be traced into the adrenal glands as well as along the renal and spermatic (or ovarian) arteries.

\section{VAGAL SYMPATHETIC PLEXUSES}

The writer has presented evidence in the series of earlier papers referred to above which shows clearly that throughout the entire vertebrate series the pulmonary, the cardiac, and the enteric plexuses, except in the aboral portions of the digestive tube, are not genetically related to the sympathetic trunks, but arise from cells of cerebrospinal origin which advance peripherally along the paths of the vagus nerves. These findings were first substantiated by Abel ('12) in embryos of the chick. Abel ('10) had previously derived the enteric plexuses in the chick exclusively from cells which migrate "from the spinal cord and the intervertebral ganglia." Following the publication of the writer's earlier papers, she undertook a reinvestigation of the development of the sympathetic nervous system in the chick. In this work she employed specialized methods and studied the development of the sympathetic plexuses related to the vagi in considerable detail. Her findings regarding the dvelopment of the pulmonary, the cardiac, and the enteric plexuses agree in all essential respects with the results of the work of the present writer which had previously been published. Recently Stewart ('20) has presented evidence based on embryos of the rat which he interprets as indicating "that part if not all of the nerve cells found in the 
cardiac, gastric, tracheal, oesophageal, pulmonary, and upper intestinal plexuses are of vagus origin."

The present series of observations on human embryos agree, with regard to the genetic relationship of the pulmonary, the cardiac, and the enteric plexuses to the vagus nerves, with the earlier observations of the writer on embryos of other vertebrates. In human embryos $5 \mathrm{~mm}$. in length, in which the primordia of the sympathetic trunks are present only in the thoracic and upper abdominal regions, the vagus nerves may be traced distally somewhat beyond the bifurcation of the trachea. Branches of the vagi bearing small accumulations of cells of nervous origin come into close proximity with the oesophageal wall. In embryos of this stage as well as in embryos which are somewhat farther advanced the vagus nerves have the appearance characteristic of nerve trunks along which cells of cerebrospinal origin migrate peripherally. In favorable sections continuous lines of cells of medullary origin may be observed extending into the vagus rootlets (fig. $3, B$ ), indicating an active migratory process. In sagittal sections the ganglia on the vagus trunks appear as large oval or elliptical cell-masses which are not sharply limited distally. Furthermore, cells identical in appearance with those present in the ganglionic masses are present in abundance in the nerve trunks as far as the latter may be traced. These cells are identical in appearance also with those which migrate peripherally along the spinal nerves and the communicating rami.

In embryos $6 \mathrm{~mm}$. in length (nos. 241 and 676) branches of the vagi may be traced distally as far as the cardiac region of the stomach and for a short distance along its lesser curvature. Wherever vagus fibers occur in these embryos they are accompanied by cells of nervous origin, many of which occur in small aggregates. The primordia of the oesophageal plexuses may be recognized at this stage. Vagus fibers accompanied by cells of nervous origin may also be traced along the bronchi toward the roots of the lungs. In embryos 7 to $9 \mathrm{~mm}$. in length all of these nervous complexuses have become better developed, the cellaggregates also have become more numerous and many of them are larger. In sagittal sections of an embryo $9 \mathrm{~mm}$. in length a 
distinct vagus branch accompanied by migrant cells may be traced into proximity with the bulbar region of the heart. This nerve gradually becomes larger and cells become aggregated near its distal end. In an embryo $14 \mathrm{~mm}$. in length (no. 511) it shows a considerable accumulation of these migrant cells near its distal extremity, as illustrated in the accompanying figure (fig. 4) which is taken from the microphotograph of a sagittal section shown in figure 15. This mass of cells constitutes a portion of the primordium of the cardiac plexus. Over the dorsal aspect of the heart the plexiform network around the oesophagus comes into very close proximity with the atrial walls. In transverse sections of an embryo $10.1 \mathrm{~mm}$. in length (no. 623) the oesophageal plexus is very conspicuous (figs. 5, 18, and 19). The branches of the vagi with their accompanying cell-aggregates form a plexiform network including many cell-masses which is somewhat richer over the dorsal and lateral aspects of the oesophagus than between the latter and the trachea. Below the bifurcation of the trachea, vagus fibers accompanied by cells of cerebrospinal origin may be traced into the roots of the lungs where masses of cells of the same type occur in proximity with the bronchi and the pulmonary vessels (figs. $6, p p$, and $20, p p$ ). These plexiform networks which constitute the primordia of the pulmonary plexuses are continuous with the oesophageal plexus as well as with that portion of the cardiac plexus which is associated with the atrial walls.

In the writer's preparations of embryos of the pig 6 to $12 \mathrm{~mm}$. in length the oesophageal plexus is less conspicuous than in human embryos of corresponding stages; however, vagus branches accompanied by migrant cells of nervous origin are present in considerable abundance around the oesophagus. By reason of the proximity of many of these elements with the oesophageal epithelium, they were erroneously interpreted as representing mainly the primordia of the enteric plexuses. The same error in interpretation, though it is less apparent, occurs also in the writer's studies of the development of the sympathetic nervous system in the other classes of vertebrates. The primordia of the oesophageal plexus are present before either nerve cells or fibers 

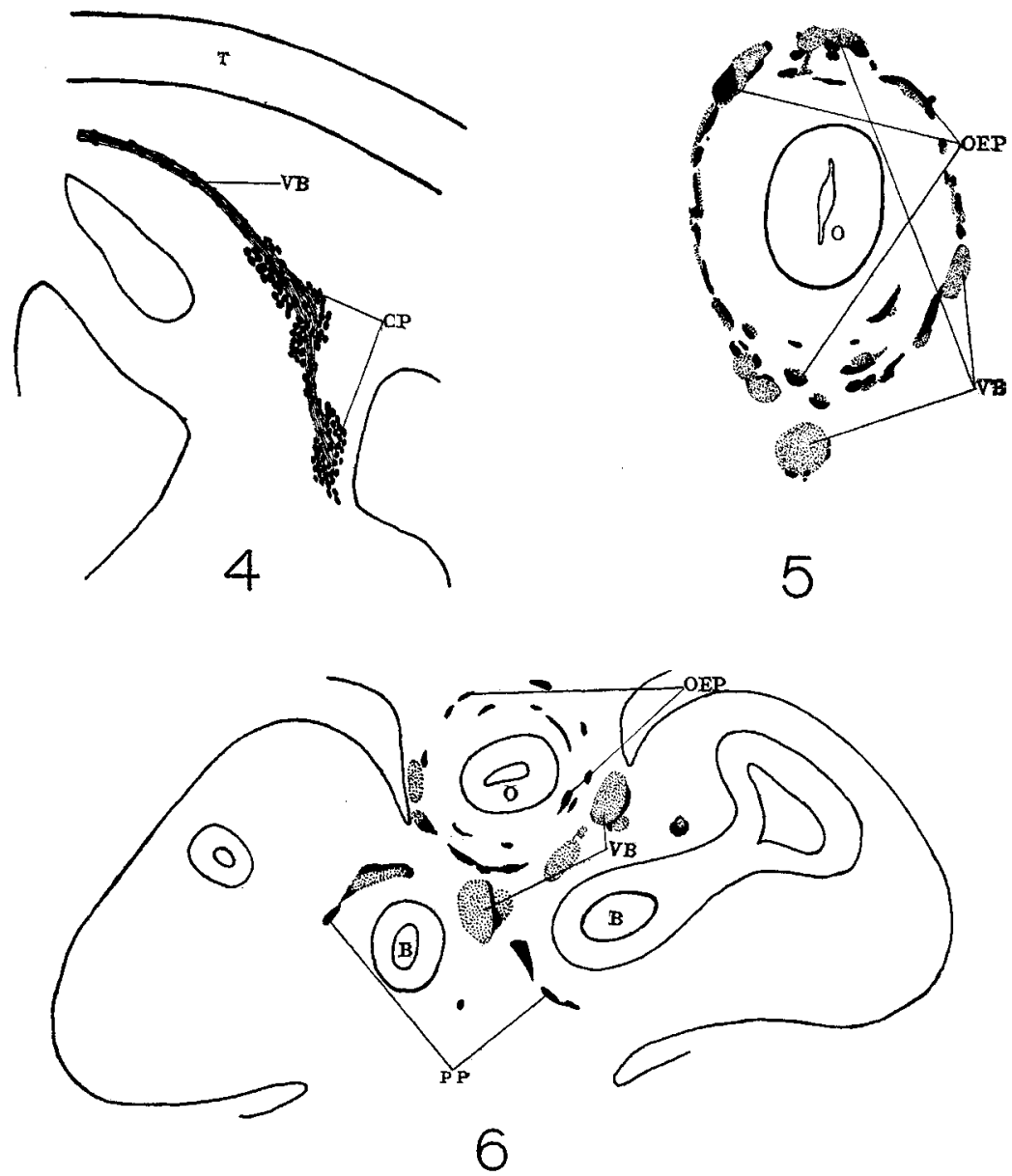

Fig. 4 Human embryo, $14 \mathrm{~mm}$. in length, 511-9-1-2×80. Sagittal section showing trachea and upper portion of heart. To be compared with figure 15 . $C P$, portion of cardiac plexus; $T$, trachea; $V B$, vagus branch to heart.

Fig. 5 Human embryo, $10.1 \mathrm{~mm}$. in length, 623-13-2-2×120. Oesophageal plexus in transverse section. To be compared with figure 19. $O E P$, cell-masses in oesophageal plexus; $O$, oesophagus; $V B$, vagus branches.

Fig. 6 Human embryo, $10.1 \mathrm{~mm}$. in length, 623-11-2-4. Transverse seetion through lungs. To be compared with figure $20 . \quad B$, bronchus; $O$, oesophagus; $O E P$, cell-masses in oesophageal plexus; $P P$, cell-masses in pulmonary plexuses; $V B$, vagus branches. 
occur within that portion of the mesenchyme which becomes differentiated into the muscular and submucous layers of the oesophageal wall. Nevertheless, some nerve cells which become incorporated in the enteric plexuses penetrate into this mesenchymal tissue very early, although they do not show a definite concentric arrangement until somewhat later. Such cells are present in considerable abundance, especially at the lower levels of the oesophagus in human embryos 7 to $9 \mathrm{~mm}$. in length. Doubtless, the above error in interpretation is in large measure responsible for the discrepancy which Stewart ('20) has emphasized between his observations on this nervous complex in embryos of the rat and those of the present writer in embryos of the pig.

In embryos $10 \mathrm{~mm}$. in length vagus branches accompanied by migrant cells are present all along the lesser curvature of the stomach in the mesenchymal tissue which is becoming differentiated to form the wall of that organ. During the succeeding stages of development vagus branches spread round the stomach and extend farther distally along the intestine. The cells which give rise to the enteric plexuses increase in number, and as the muscular and submucous layers of the wall of the digestive tube become differentiated, these minute ganglionic cell-masses become concentrically arranged in two layers which give rise to the myenteric and submucous plexuses.

It is important to note that no paths along which cells migrate from the sympathetic trunks or the prevertebral plexuses into the pulmonary, the cardiac, and the enteric plexuses in the more proximal portions of the digestive tube are established during the early stages of development. Indeed, the latter plexuses develop simultaneously with the sympathetic trunks and the prevertebral plexuses. Sympathetic nerves grow into the plexuses related to the vagi somewhat later, but not until the great majority of the cells which enter their primordia are already present. Although the possibility that some cells may be added to these plexuses after fibrous connections with the sympathetic trunks are established is not precluded, we must conclude that they arise primarily from cells of cerebrospinal origin which advance peripherally along the vagi. 
To what extent cells which advance peripherally along the vagi take part in the development of the enteric plexuses in the more distal portions of the intestine is not clear. The evidence at hand favors the conclusion that the primordia of these plexuses gradually extend distally from the upper levels of the intestine in which the cells are certainly derived from the vagus supply. On the other hand, the lower portions of the intestine, especially the large intestine, arises in close proximity with the prevertebral plexuses in the lower abdominal and pelvic regions. Paths along which sympathetic cells may migrate from these plexuses into the walls of the intestine are established relatively early. Obviously, the enteric plexuses in the lower portions of the intestine are derived from the sympathetic supply in the lower trunk region.

\section{CRANIAL SYMPATHETIC GANGLIA}

\section{Ciliary ganglion}

Doubtless the ciliary ganglion represents the most primitive of the well-defined sympathetic ganglia in the cranial region in the higher vertebrates. Its development has been studied in embryos of types of all the classes of vertebrates. The majority of the more recent investigators, including the present writer, have agreed that this ganglion arises from cells of cerebrospinal origin which advance peripherally both along the oculomotor and ophthalmic nerves. However, both Broman ('11) and Streeter ('12) failed to recognize cells which advance peripherally along the oculomotor nerve and enter the primordium of the ciliary ganglion in human embryos. They derived the ciliary exclusively from the semilunar ganglion. Ganfini ('17) pointed out that the contribution of cells from the oculomotor nerve to the ciliary ganglion is much less obvious in mammalian embryos (guinea-pig and pig) than in embryos of types of other classes of vertebrates; however, inasmuch as its double origin is clearly established in other classes of vertebrates, he concluded that this ganglion is genetically related both to the oculomotor and ophthalmic nerves also in mammals. Although Stewart ('20) maintains that all the other cranial sympathetic ganglia arise exclusively from cells 
which advance peripherally along the nerves which carry the preganglionic fibers to each respectively, he found no evidence in embryos of the rat that any of the cells which become incorporated in the ciliary ganglion advance peripherally along the oculomotor nerve.

The migration of cells along the oculomotor nerve in early human embryos is not very apparent; however, in a number of instances an aggregate of intensely staining cells was observed on the oculomotor nerve trunk at the level at which the ciliary ganglion arises before cells could be traced thither from the ophthalmic nerve. Doubtless, these cells become incorporated in the ciliary ganglion. The ophthalmic nerve in early human embryos has the appearance of a path along which active migration of cells is taking place. Continuous lines of cells extend from the semilunar ganglion along this nerve trunk. Migrant ganglion cells become aggregated very early at a point just proximal to the origin of the nasociliary ramus. As this aggregate of cells grows larger, it advances toward the oculomotor nerve until it makes intimate contact with the latter at the point at which the aggregate of cells noted above is located. When this is accomplished the primordium of the ciliary ganglion consists of a continuous mass of cells extending from the ophthalmic to the oculomotor nerve. This condition, as it appears in sagittal sections of an embryo $14 \mathrm{~mm}$. in length, is illustrated in the accompanying figure (fig. 7) which is taken from the microphotograph in figure 21. Nerve fibers may be traced from the ophthalmic nerve into the primordium of the ciliary ganglion at this stage, but they are largely obscured by the densely aggregated cells. As development advances this ganglionic mass becomes somewhat removed from the ophthalmic nerve trunk, but remains in intimate contact with the oculomotor nerve until relatively late. As compared with the total number of cells comprised in the primordium of the ciliary ganglion in human embryos, the small group of cells which becomes aggregated early on the oculomotor nerve is relatively unimportant. Nevertheless, the evidence warrants the conclusion that in human embryos, as in the embryos of other vertebrates, the ciliary ganglion is genetically related both to the ophthalmic and the oculomotor nerve. 

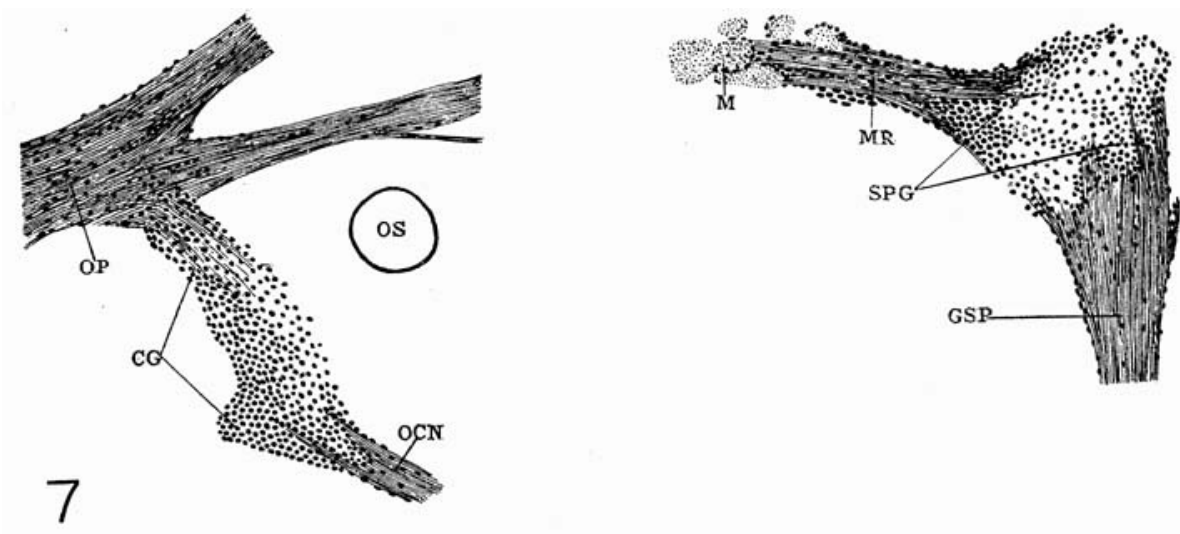

8

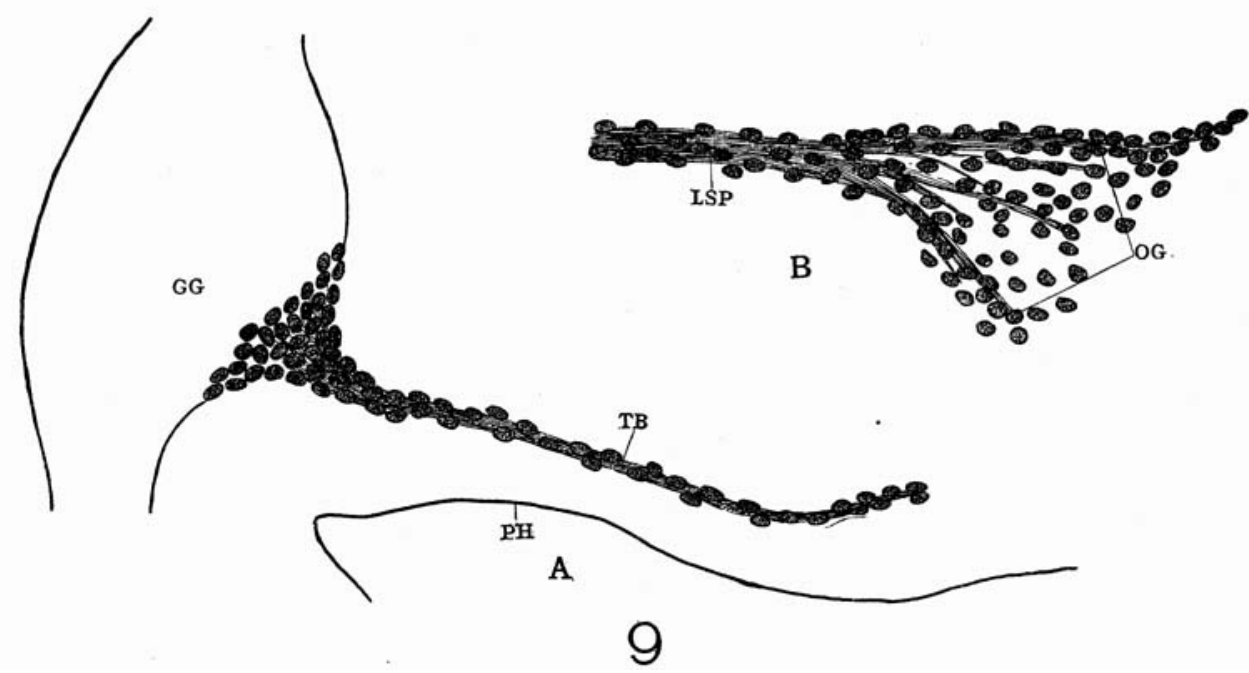

Fig. 7 Human embryo, $14 \mathrm{~mm}$. in length, $511-12-2-2 \times 80$. Sagittal section through ciliary ganglion. To be compared with figure 21. $C G$, eiliary ganglion; $O C N$, oculomotor nerve; $O P$, ophthalmic nerve; $O S$, optic stalk.

Fig. 8 Human embryo, $20 \mathrm{~mm}$. in length, 462-15-1-1×80. Section showing sphenopalatine ganglion with maxillary ramus and nerve of the pterygoid canal entering it. To be compared with figure 25. GSP, nerve of the pterygoid canal; $M$, maxillary nerve; $M R$, maxillary ramus to sphenopalatine ganglion; $S P G$, sphenopalatine ganglion.

Fig. 9 A. Human embryo, $7.85 \mathrm{~mm}$. in length, 1354-5-3. Sagittal section showing geniculate ganglion $(G G)$ and tympanic nerve $(T P)$. $P H$, posterior wall of pharyns. B. Human embryo $14 \mathrm{~mm}$. in length, $411-4-2-1$. Sagittal section showing otic ganglion $(O G)$ and lesser superficial petrosal nerve $(L S P)$. 


\section{Sphenopalatine ganglion}

The primordium of the sphenopalatine ganglion arises at the growing tip of the greater superficial petrosal nerve as an aggregate of cells which advance from the geniculate ganglion along the path of this nerve. The earliest human embryos in which it was observed are $11 \mathrm{~mm}$. in length (nos. 619 and 1836). The geniculate ganglion is not sharply limited during early development, but cells advance from its distal border along the fibers of the great superficial petrosal nerve. Cells of this type are present throughout the entire length of this nerve; consequently, it presents, during these early stages, the appearance characteristic of a slender nerve trunk along which cells of cerebrospinal origin advance peripherally.

This primordium of the sphenopalatine ganglion lies medial to, but not in contact with the maxillary nerve. This nerve is composed of numerous loosely aggregated bundles of fibers. Cells become separated from the semilunar ganglion and advance peripherally along these fiber bundles either singly or in small aggregates. In embryos 12 to $15 \mathrm{~mm}$. in length rami deviate from the maxillary nerve near its origin from the semilunar ganglion and grow into the primordium of the sphenopalatine ganglion. Cells of ganglionic origin advance along these rami and become aggregated at their growing tips. This condition, as it appears in coronal sections of an embryo $14.6 \mathrm{~mm}$. in length (no. 1919), is illustrated in figure 23. Sections which cut the maxillary nerve approximately at right angles at the level of the sphenopalatine ganglion in embryos $15 \mathrm{~mm}$. and over in length show a fibrous ramus accompanied by numerous cells of nervous origin which extends from the maxillary nerve into the primordium of this ganglion. The same condition still obtains in embryos 20 and 21 mm. in length (nos. 462 and 460). Figures 8, 24, 25, and 26 are taken from sections of these embryos which show both a maxillary ramus and the nerve of the pterygoid canal, which comprises the fibers of the greater superficial petrosal nerve, growing into the primordium of the sphenopalatine ganglion. They show clearly that numerous migrant cells are still present along the 
maxillary ramus, while the nerve of the pterygoid canal is relatively free from cells. Obviously, migration of cells into the sphenopalatine ganglion continues longer from the semilunar than from the geniculate ganglion. That the cells associated with the rami of the maxillary nerve which enter the sphenopalatine ganglion are at least in part cells which become differentiated into neurones is evidenced by the fact that in embryos $20 \mathrm{~mm}$. and over in length many of them may be recognized as neuroblasts. Furthermore, as observed by Macklin, ${ }^{5}$ ganglionic masses of neuroblasts occur on these rami or at their origin from the maxillary nerve in embryos $40 \mathrm{~mm}$. and over in length. The deep petrosal joins the greater superficial petrosal nerve before migration of cells along the fibers of the latter ceases; however, there is no clear evidence that cells which accompany the fibers of the deep petrosal nerve enter the sphenopalatine ganglion.

The observations here set forth justify the conclusion that in human embryos the sphenopalatine ganglion arises in part from cells which advance from the geniculate ganglion along the greater superficial petrosal nerve and in part from cells which advance from the semilunar ganglion along the maxillary nerve and its rami. Obviously, the contribution of cells from the latter source is greater than that from the former. The writer's earlier observations on the development of the sphenopalatine ganglion in embryos of the pig ('13) led him to the conclusion that this ganglion arises primarily from cells which advance from the semilunar ganglion along the maxillary nerve and its rami, and that it receives relatively few cells from the geniculate ganglion via the greater superficial petrosal nerve. A reinvestigation of the development of this ganglion in embryos of the pig has convinced the writer that he failed in his earlier work to recognize the greater superficial petrosal nerve as a migration path until cells could already be traced from the semilunar ganglion into the primordium of the sphenopalatine ganglion. In embryos of the pig, as in human embryos, the earliest cells which enter the primordium of the sphenopalatine ganglion advance peripherally along the greater superficial petrosal nerve. Nevertheless, the

5 Unpublished communication. 
majority of the cells which enter the primordium of this ganglion are derived from the semilunar ganglion along the maxillary nerve and its rami.

The recent work of Ganfini ('17) shows clèarly that the majority of the cells which enter the primordium of the sphenopalatine ganglion in mammalian embryos (guinea-pig and pig) advance from the semilunar ganglion along the maxillary nerve and its rami. His description of the earliest maxillary rami entering the primordium of the sphenopalatine ganglion as bundles of fibers which deviate from the maxillary nerve near its origin from the semilunar ganglion is in full accord with the conditions in human embryos described above and illustrated microphotographically in figure 23. Ganfini does not consider the cells which may enter the sphenopalatine ganglion via the greater superficial petrosal nerve of any considerable importance in its development.

Stewart ('20) maintains that both in embryos of the pig' and the rat the sphenopalatine ganglion arises exclusively from cells which advance from the geniculate ganglion along the greater superficial petrosal nerve. In the light of the observations on human embryos set forth above as well as the work of Broman ('11) and Streeter ('12) on human embryos and that of Ganfini ('17) on embryos of other mammalian types, the contribution of cells from the semilunar to the primordium of the sphenopalatine ganglion seems to be so clearly demonstrated that it does not seem advisable at this time to discuss the evidence bearing on this point any further.

\section{Otic ganglion}

The primordium of the otic ganglion arises in human embryos as an accumulation of cells at the growing extremity of the lesser superficial petrosal nerve. In embryos 7 to $8 \mathrm{~mm}$. $\mathrm{n}$ length the tympanic branch of the glossopharyngeal nerve may be traced from the petrosal ganglion along the dorsal aspect of the pharynx as a slender ramus with which are associated numerous cells which are identical with those in the petrosal ganglion. Cells apparently advance from the petrosal ganglion into this ramus and migrate along its course. In sagittal sections of an embryo 7.85 $\mathrm{mm}$. in length (no. 1354) this ramus may be traced from the petrosal ganglion nearly to the level of the geniculate ganglion. There are no marked accumulations of cells along its course, but 
the entire ramus, as illustrated in the accompanying figure (fig. 9 A), contains numerous cells of nervous origin and presents the appearance of an early migration path. In embryos $10 \mathrm{~mm}$. in length the tympanic nerve has been joined by fibers from the geniculate ganglion. The lesser superficial petrosal nerve may now be traced to a point a little below the level of the semilunar ganglion where a small mass of cells has become aggregated. In an embryo $14 \mathrm{~mm}$. in length (no. 511) this mass has become somewhat larger, but the cells are still loosely aggregated. In sagittal sections of this embryo, as illustrated in figure $9 \mathrm{~B}$, it is irregularly triangular and its upper angle comes into very close proximity with the semilunar ganglion. In sections of an embryo 13 mm. in length (no. 485), as illustrated microphotographically in figure 22, there is apparent cellular continuity between the primoridum of the otic ganglion and the semilunar ganglion. This connection could not be observed in all embryos in approximately the same phase of development. In embryos $14 \mathrm{~mm}$. and over in length the primiordium of the otic ganglion lies in intimate contact with the mandibular division of the trigeminal nerve. This nerve, like the other divisions of the trigeminal, contains numerous cells of cerebrospinal origin which apparently advance distally along its course. Many of these cells are derived from the semilunar ganglion, others probably advance from the rhombencephalon along the motor root of the trigeminal nerve. Even in relatively late stages, as illustrated in figure 30 which is taken from a section of an embryo $14.5 \mathrm{~mm}$. in length (no. 1267) continuous rows of cells may be traced from the rhombencephalic wall into the motor root of the trigeminal nerve. Doubtless, many of these cells advance peripherally along the motor fibers of the mandibular nerve. Fibrous rami may now be traced from the mandibular nerve into the otic ganglion. These rami, like the rami of the maxillary nerve which enter the sphenopalatine ganglion, are accompanied by migrant cells, some of which apparently advance into the otic ganglion. This condition obtains during a considerable interval. In embryos 20 and $21 \mathrm{~mm}$. in length (nos. 460 and 462), as illustrated in figures 10, 27 and 28, the rami of the mandibular nerve leading into the otic ganglion 

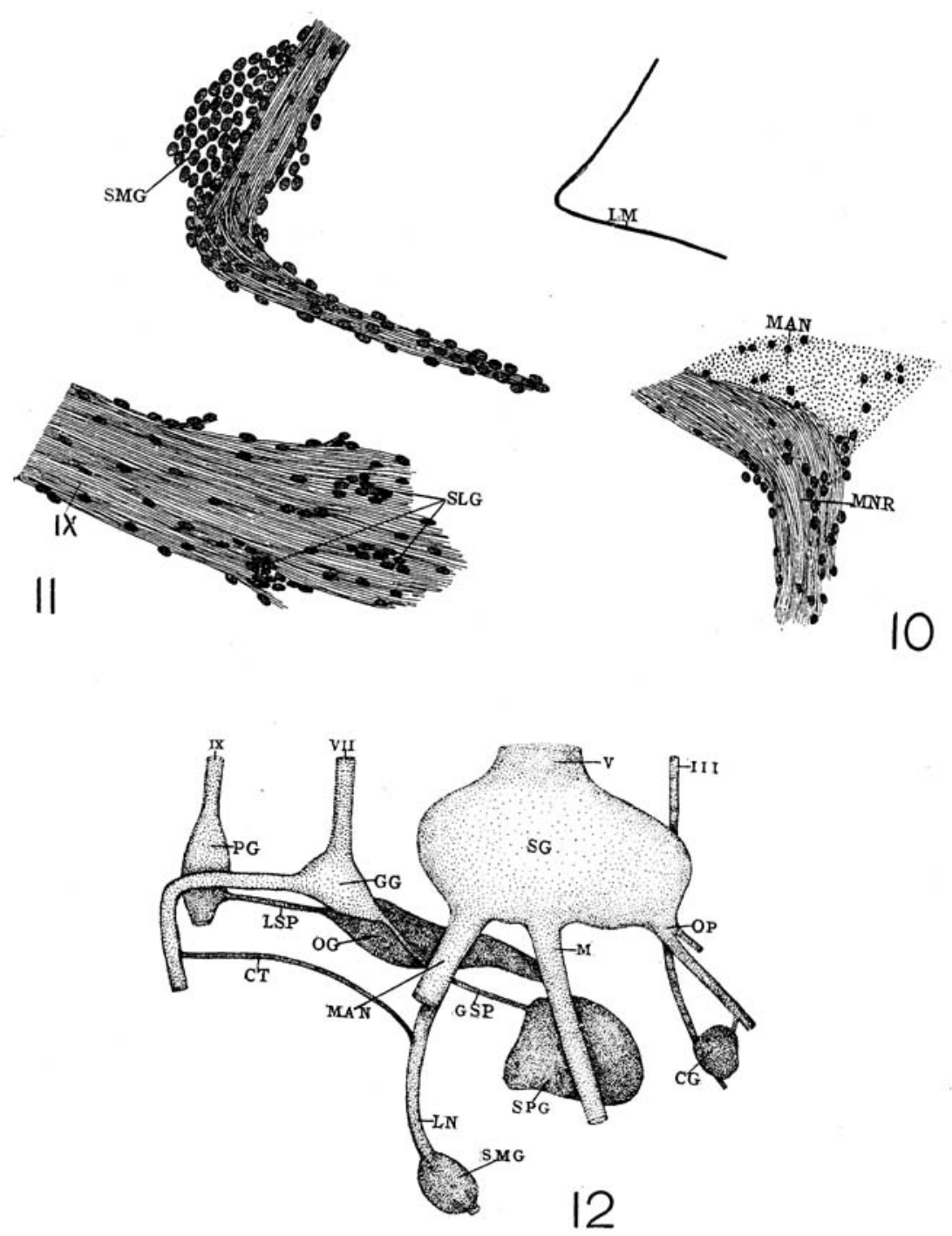

Fig. 10 Human embryo, $20 \mathrm{~mm}$. in length, 462-14-2-3×165. Section through mandibular nerve and ramus to otic ganglion. To be compared with figure 27. $M A N$, mandibular nerve; $M N K$, mandibular ramus to otic ganglion.

Fig. 11 Human embryo, $14 \mathrm{~mm}$. in length, 940-14-2-3×160. Section through tongue. $I X$, lingual ramus of glossopharyngeal nerve; $L M$, margin of tongue; $S M G$, submaxillary ganglion; $S L G$, ganglionic masses associated with glossopharyngeal nerve.

Fig. 12 Diagrammatic reconstruction of the larger cranial sympathetic ganglia and the nerves to which they are genetically related in an embryo about 20 $\mathrm{mm}$. in length. $C G$, ciliary ganglion; $C T$, chorda tympani; $G G$, geniculate ganglion; GSP, greater superficial petrosal nerve; $L N$, lingual nerve; $L S P$, lesser superficial petrosal nerve; $M$, maxillary nerve; $M A N$, mandibular nerve; $O G$, otic ganglion; $O P$, ophthalmic nerve; $P G$, petrosal ganglion; $S G$, semilunar ganglion; $S M G$, submaxillary ganglion; $S P G$, sphenopalatine ganglion. 
still contains small aggregates of ganglion cells. Migrant cells are always more numerous at the periphery than in the interior of the larger nerve trunks. Inasmuch as the otic ganglion lies in immediate contact with the mandibular nerve, many of the cells advancing distally at the periphery of this nerve doubtless become incorporated in the ganglion. At any rate, a contribution of cells from the mandibular nerve to the otic ganglion cannot be precluded. Indeed, the majority of the cells which enter the otic ganglion probably come from this source. As in the case of the sphenopalatine ganglion, it may be observed that migration of cells into the otic ganglion continues later along the trigeminal fibers than along the other contributing path. Therefore, we are forced to conclude that, while the early primordium of the otic ganglion arises at the growing extremity of the lesser superficial petrosal nerve primarily from cells which advance from the petrosal ganglion, the majority of the cells which enter this ganglion are derived from the semilunar ganglion and the motor root of the trigeminal nerve.

In embryos $14 \mathrm{~mm}$. and over in length the otic and sphenopalatine ganglia are connected with each other by a cellular strand (fig. 29). This cellular connection was observed in embryos up to $21 \mathrm{~mm}$. in length, but not in later stages. It probably undergoes retrogressive changes during later development. The significance of this connection, if it has any, could not be determined.

The writer's earlier observations on the development of the otic ganglion in embryos of the pig led him to conclude that this ganglion arises primarily from cells of trigeminal origin. Further observations on early pig embryos have convinced him that he failed in his earlier work to recognize the lesser superficial petrosal nerve as a path along which cells advance into the otic ganglion until the period of most active migration along this path had elapsed. In embryos of the pig, as in human embryos, the first cells which enter the primordium of the otic ganglion advance peripherally along the lesser superficial petrosal nerve primarily from the petrosal ganglion, while the majority of the cells which enter this ganglion advance peripherally along the mandibular nerve and its rami. 
The writer desires at this time to call attention to an error in his earlier work on the development of the otic ganglion in embryos of the chick ('14). In this instance the tympanic nerve was not recognized as a path along which cells migrate cephalad from the petrosal ganglion. The fibrous ramus which emerges from the plexuses on the internal carotid artery to join the tympanic nerve in the formation of the lesser superficial petrosal nerve is relatively large in embryos of the chick and shows some migrant cells. Having no sagittal sections of the earlier stages at hand, it was erroneously concluded that the majority of the cells which enter the otic ganglion advance from the plexus on the internal carotid artery. The writer is now of the opinion that relatively few if any cells reach the otic ganglion from this source, but that in embryos of the chick, as in mammalian embryos, the cells which enter the otic ganglion from other than trigeminal sources advance along the lesser superficial petrosal nerve primarily from the petrosal ganglion. A contribution of cells to the otic ganglion from trigeminal sources is less obvious in embryos of the chick than in mammalian embryos. Nevertheless, in the light of comparative studies, it cannot be excluded.

Broman('11) and Streeter ('12), who studied the development of the otic ganglion in human embryos, and Ganfini ('17), who employed embryos of other mammalian types (guinea-pig and pig), concur in the opinion that this ganglion is derived exclusively from the semilunar ganglion. On the other hand, Stewart ('20), basing his conclusions on observations made on embryos of the pig and the rat, maintains that the otic ganglion arises exclusively from cells which advance peripherally along the lesser superficial petrosal nerve.

\section{Submaxillary ganglion}

The primordium of the submaxillary ganglion arises relatively early in human embryos as an accumulation of cells in the path of the lingual division of the mandibular nerve. In embryos 10 to $11 \mathrm{~mm}$. in length in which only the merest traces of the primordia of the sphenopalatine and otic ganglia are present the primordium of the submaxillary ganglion has already attained 
considerable size. In view of the double origin of the other sympathetic ganglia associated with the trigeminal nerve, we should expect that both cells of trigeminal and of facial origin should take part in the development of the submaxillary ganglion. The writer could not, in embryos 10 to $11 \mathrm{~mm}$. in length, trace the chorda tympani to its junction with the lingual nerve. Neither did he succeed in determining the exact phase of development in which this junction is effected. However, in view of the condition of the other rami of the facial nerve, especially the greater superficial petrosal nerve, in embryos in which the earliest traces of the submaxillary ganglion appear, it is safe to conclude that cells are aggregated in the path of the lingual nerve before the junction of the chorda tympani with the latter is effected. Therefore, the further conclusion that the earliest cells which enter the primordium of the submaxillary ganglion are cells of trigeminal origin is also justified. It is quite probable that cells which advance from the facial nerve along the chorda tympani enter the primordium of the submaxillary ganglion after the junction of the chorda tympani with the lingual nerve has been effected. The primordium of this ganglion increases in size relatively rapidly. In an embryo $13 \mathrm{~mm}$. in length (no. 485), as illustrated in figure 31 , the submaxillary ganglion is represented by a relatively large mass of cells. In sections of embryos $12 \mathrm{~mm}$. and over in length which cut the lingual nerve transversely at the level of the submaxillary ganglion, this mass of cells completely encircles the lingual nerve trunk. This condition obtains for a considerable interval following the $12-\mathrm{mm}$. stage. In view of the early phase of development represented by embryos 12 and $13 \mathrm{~mm}$. in length, it is inconceivable that any considerable portion of the cell-mass which constitutes the primordium of the submaxillary ganglion at this stage arose from cells which have advanced thither from the facial nerve. Therefore, we must conclude that the submaxillary ganglion arises primarily from cells of trigeminal origin which advance distally along the lingual division of the trigeminal nerve. This conclusion is in accord with the work of Broman ('11) and Streeter ('12). Ganfini ('17) does not admit that in embryos of the guinea-pig and 
the pig any cells enter the submaxillary ganglion from sources other than the semilunar ganglion.

In keeping with his conclusion that the sphenopalatine and otic ganglia are derived exclusively from cells which advance peripherally along the greater superficial petrosal and the lesser superficial petrosal nerves, respectively, Stewart ('20) has concluded that the submaxillary ganglion arises exclusively from cells which advance peripherally along the chorda tympani. In view of the intimate relationship of the primordium of the submaxillary ganglion with the lingual nerve, he admits that direct observations can lend little support to this conclusion. Obviously, however, it is demanded by the theory that these several ganglia rise exclusively from cells which advance peripherally along the nerve trunks which later carry the preganglionic fibers to each ganglion respectively.

\section{Sublingual and lingual ganglia}

As the lingual nerve grows distally beyond the primordium of the submaxillary ganglion, as observed in embryos $12 \mathrm{~mm}$. and over in length, its fibers are accompanied by numerous migrant cells. Some of these cells have become aggregated in the path of the nerve to give rise to the sublingual ganglion, while others advance along the branches of the lingual nerve to give rise to the smaller ganglionic masses in the tongue which remain associated with the lingual rami. Obviously, the larger sublingual ganglion and the smaller ganglionic masses associated with the rami of the lingual nerve arise from cells whose sources are essentially the same as those of the cells which give rise to the submaxillary ganglion.

The small sympathetic ganglia in the posterior portion of the tongue arise in association with the lingual ramus of the glossopharyngeal nerve. During the early developmental stages this nerve also contains cells of cerebrospinal origin. As the lingual ramus grows into the tongue aggregates of cells occur near its growing extremity (fig. 11, SLG). Some of these cell-groups remain closely associated with the nerve trunk, while other cells 
advance along its branches and give rise to minute sympathetic ganglia throughout the portion of the tongue which is innervated by the glossopharyngeal nerve.

\section{SOURCES OF THE SYMPATHETIC NEURONES}

A review of the literature indicates that all the earlier investigators who recognized the ectodermal origin of the sympathetic nervous system supported the theory that the cells which give rise to the sympathetic primordia are in some manner derived from the cerebrospinal ganglia (or neural crest). Following the introduction of the principle of the migration of these cells by His, Jr. ('91), all, except the advocates of the theory of local differentiation and the multicellular nature of nerve fibers, supported a theory according to which these cells either migrate along the fibrous paths of cerebrospinal nerves and communicating rami or in advance of these fibers either along the paths later occupied by them or directly through the mesenchyme. It was early observed that cells identical in appearance with those which migrate from the spinal ganglia into the primordia of the sympathetic trunks are present in the ventral roots of the spinal nerves from the very beginning of the period of migration. It was also observed that cells of nervous origin migrate from the walls of the neural tube into the motor roots of the spinal and certain of the cranial nerves. Such observations made on embryos of the lower vertebrates, especially the Elasmobranchii, indicate that cells of medullary origin migrate into the motor roots of the spinal nerves in considerable abundance. In embryos of the higher vertebrates an abundant migration of such cells into the motor nerve roots is less apparent. Nevertheless, the recorded observations justify the conclusion that many of the cells which advance peripherally along the spinal nerves are derived from the ventral half of the neural tube. In spite of the knowledge of the presence of these cells of medullary origin in the paths along which cells advance into the primordia of the sympathetic trunks, they have not generally been considered of any consequence in the development of the sympathetic nervous system. 
Hoffmann ('00), who made careful observations on Elasmobranch embryos, was among the earliest investigators who concluded that some of the sympathetic elements are derived from the neural tube via the ventral roots of the spinal nerves. Harrison ('01) was led to the same conclusion by his observations on embryos of the salmon. This conclusion was further supported by Harrison's ('04) experimental observations on amphibian larvae. Neumayer ('06), though not an advocate of the migration theory, inferred from his observations on embryos of Lacerta and the chick that the sympathetic primordia are derived both from cells in the dorsal and the ventral nerve roots. Carpenter ('06) recognized the cells which migrate from the wall of the midbrain along the oculomotor and the abducent nerves, in embryos of the chick, as the 'indifferent' cells of Schaper, i.e., cells which have the capacity either to develop into neurones or supporting elements. He further observed that some of the cells of this type associated with the oculomotor nerve become incorporated in the ciliary ganglion.

Froriep ('07) was perhaps the first investigator who vigorously supported the theory that cells of medullary origin which advance peripherally along the motor roots of the cerebrospinal nerves play an important part in the development of the sympathetic nervous system. Indeed, he concluded that all sympathetic neurones are derived from cells which have their origin in the ventral half of the neural tube. His observationswere based on embryos of Torpedo and the rabbit. Cajal ('08) drow essentially the same conclusion from his observations on embryos of the chick. By the aid of his own specialized technique he recognized elements in the motor roots of the spinal and certain of the cranial nerves as nerve cells in the bipolar phase. His observations show clearly that at least some of the cells which migrate from the medullary tube into the motor nerve roots become differentiated into neurones.

As far as the writer has been able to ascertain, Froriep and Cajal are the only investigators who have supported the theory that the sympathetic neurones are derived exclusively from cells which have their origin in the ventral half of the neural tube and 
migrate peripherally along the motor nerve roots. The several other investigators cited above seem to favor the theory that the sympathetic system is derived in part from cells which have their origin in the cerebrospinal ganglia (or neural crest) and in part from cells which have their origin in the ventral half of the neural tube. This theory is supported also by the writer's observations on embryos of types of the several classes of vertebrates as well as by the work of Abel ('12) on embryos of the chick and the extensive work of Ganfini ('11-'18) on embryos of various types of vertebrates.

Held ('09) and Marcus ('09) are among the most recent investigators who still maintain that the sympathetic nervous system is derived exclusively from the cerebrospinal ganglia or the neural crest. From observations made on embryos of Elasmobranchii, Held argued that the cells present in the motor roots of the spinal nerves play no part in the development of the sympathetic trunks because, in these embryos, the primordia of the sympathetic ganglia lie in contact with the sensory and not with the motor nerve roots and there are no cellular connections apparent between the latter and the former. Furthermore, the motor roots apparently contain fewer cells than the sensory roots.

The writer's observations on embryos of Acanthias suggest that Held's conclusions are based on observations made on embryos which were somewhat too far advanced in their development to reveal the true relationship of the primordia of the sympathetic trunks to the motor roots of the spinal nerves. As has frequently been observed, cells migrate from the ventral part of the neural tube into the ventral roots of the spinal nerves in great abundance in early elasmobranch embryos. Indeed Balfour ('77) described the ventral nerve root in such embryos as "an elongate cellular structure with a wide attachment to the spinal cord." In transverse sections of early embryos of Acanthias stained by the iron-hematoxylin method it may be observed, as the writer has shown in an earlier paper ('11), that some of these cells, as they advance peripherally, become scattered in the mesenchymal tissue along the dorsolateral aspects of the aorta with other cells of neural crest origin and later become 
incorporated in the primordia of the sympathetic trunks. In embryos which are somewhat further advanced in their development the primordia of the sympathetic ganglia appear in contact with the sensory and not with the motor roots of the spinal nerves, as described by Held. After this condition obtains the genetic relationship of the sympathetic ganglia to the motor roots of the spinal nerves is no longer apparent.

Neal ('14) has taken exception to these findings. He admits the possibility that cells of medullary origin may enter the sympathetic primordia, but he insists that the present writer has "presented no facts which make this inference seem more certain." Indeed, he does not admit that the evidence presented indicates that cells of cerebrospinal origin become scattered in the mesenchymal tissue along the dorsolateral aspects of the aorta. $\mathrm{He}$ seems to regard the differentiation upon which the writer based his conclusion that certain cells present in this mesenchymal tissue in sections of early embryos of Acanthias are cells of cerebrospinal origin which have migrated thither as the creation of a too vivid imagination. The interpretation of these cells was based on the size, character, and staining qualities of their nuclei. These are the criteria which have commonly been employed in the recognition of cells of nervous origin lying outside the cerebrospinal nervous system in early embryos. Cells of this type are present in considerable abundance in the mesenchymal tissue along the dorsolateral aspects of the aorta just before the primordia of the ganglia of the sympathetic trunks appear as compact cell-masses, but gradually become less abundant as these cell-masses increase in size. This fact was interpreted as evidence that these cells become incorporated in the primordia of the sympathetic trunks. It might have been pointed out further that it would be quite impossible to account for all the cells present in the motor roots of the spinal nerves in early embryos of Acanthias by the number of cells associated with the fibers of these motor roots soon after the primordia of the ganglia of the sympathetic trunks appear as compact cell-masses in contact with the sensory roots of the spinal nerves. Neither can the rapid increase in size of these ganglionic masses following their earliest 
appearance be accounted for by migration of cells along the sensory nerve root and local cell division alone.

A study of Neal's paper seems to justify the inference that he does not admit that cells of cerebrospinal origin either migrate in advance of the growing nerve fibers or deviate from the course of the latter. His observations are based largely on material prepared by the method of vom Rath. Since the observations referred to above were published the writer has had occasion to study a series of embryos of Acanthias prepared by the vom Rath method. This method brings out the early nerve fibers much more distinctly than does the iron-hematoxylin method; however, it does not differentiate cells of nervous origin from cells of mesenchymal origin as clearly as does the latter method. Doubtless, fibers are present in the nerve roots somewhat earlier than the writer observed them in his earlier work. However, the important question at issue is, do any cells of medullary and neural crest origin deviate from the course of the motor and sensory roots of the spinal nerves respectively as they advance peripherally? For evidence on this point we need not depend on the observations of the present writer nor on embryos of the Elasmobranchii alone. As indicated by the work of well-known investigators referred to in this paper, the migration of cells of cerebrospinal origin in advance of the growing nerve fibers and directly through mesenchymal tissue outside the paths of the growing nerves has been observed repeatedly in embryos of various types of vertebrates.

At this point the writer would call attention to the very careful work of Ganfini ('11) on the development of the sympathetic nervous system in fishes. In early embryos of Amia, a ganoid type, Ganfini observed that cells of medullary origin which advance peripherally in the motor roots of the spinal nerves deviate from the path of the motor fibers and advancing toward the aorta become scattered in the mesenchymal tissue along its dorsolateral aspects. These cells, according to Ganfini, with cells which advance from the spinal ganglia along the sensory roots of the spinal nerves, become incorporated in the primordia of the sympathetic trunks. These findings in embryos of Amia corroborate 
the findings of the present writer in embryos of Acanthias. Indeed, the evidence seemed so clear to Ganfini that he expressed surprise that, after having described this condition in embryos of Acanthias, the writer should have failed to describe it in embryos of Amia. By way of explanation it may be said here that the cells of nervous origin did not react to the iron-hematoxylin method in the embryos of Amia at the writer's disposal as they did in the embryos of Acanthias. Therefore, he was unable to recognize cells of this type scattered in the mesenchymal tissue. It seems entirely probable that the primordia of the sympathetic trunks arise in essentially the same manner both in embryos of Acanthias and Amia. Therefore, the findings of Ganfini in embryos of Amia are highly gratifying.

In view of the more recent work on the development of the sympathetic nervous system, especially the extensive work of Ganfini, the evidence that cells of medullary origin which advance peripherally along the motor nerve roots become incorporated in the sympathetic primordia in embryos of all classes of vertebrates seems to the writer conclusive. That cells of neuralcrest origin take part in the development of the sympathetic nervous system has been very generally conceded. The present series of observations on human embryos is in full accord with this conception. Precisely what part the cells from each of these two sources play in the development of the sympathetic nervous system cannot be determined at present.

That both cells of medullary and of neural crest origin enter the primordia of the vagal sympathetic plexuses and certain of the cranial sympathetic ganglia is not apparent. The cells which may be traced from the wall of the hindbrain into the rootlets of the vagi are identical in appearance with the cells which become separated from the distal ends of the ganglia on the vagus trunks and advance farther peripherally; therefore, it is quite impossible to identify cells of medullary origin along the vagi distal to the ganglia on their trunks. Likewise, the cells which migrate from the wall of the hindbrain into the rootlets of the glossopharyngeal nerve cannot be traced with certainty beyond the petrosal ganglion along the lesser superficial petrosal nerve. 
Neither can cells of medullary origin in the rootlets of the facial nerve be traced beyond the geniculate ganglion along the greater superficial petrosal nerve. On the other hand, the presence of one or more ganglia on a nerve trunk does not preclude the possibility that cells of medullary origin may advance along the path of the latter. Consequently, cells derived from the walls of the hindbrain may advance along the vagi into the primordia of the vagal sympathetic plexuses or along the lesser superficial petrosal and greater superficial petrosal nerves, respectively, into the otic and sphenopalatine ganglia. Indeed, if we must admit a double origin for parts of the sympathetic nervous system, there is no good reason to assume that any part of it is derived exclusively from cells which have their origin in the neural crest.

This theory of the double origin of the sympathetic nervous system does not imply that all the cells which become differentiated into sympathetic neurones actually migrate from the cerebrospinal nervous system into the sympathetic primordia. As pointed out above, Carpenter ('06) interpreted the cells which migrate from the midbrain along the oculomotor nerve in embryos of the chick as the 'indifferent' cells of Schaper, i.e., cells which have the capacity either to develop into neurones or supporting elements. The writer, in an earlier paper ('10), presented evidence which supports the conclusion that the cells which migrate from the cerebrospinal nervous system toward the sympathetic primordia in mammalian (pig) embryos are of the same type. The present series of observations on human embryos justifies the same conclusion. Schaper ('97) pointed out that the 'indifferent' cells which arise by the mitotic division of the 'germinal' cells of His do not become differentiated at once, but retain the capacity for further division by which they give rise to new generations of indifferent cells which in turn become differentiated into neurones or supporting elements. As observed in the earlier work referred to above, many of the cells of cerebrospinal origin which migrate peripherally undergo mitotic division along the course of migration or in the sympathetic primordia. The cells which migrate toward the sympathetic primordia in human embryos behave in the same manner. Mitotic figures are not un- 
common both along the paths of migration and in the primordia of the sympathetic ganglia. Therefore, we must conclude that many of the elements which become differentiated into sympathetic neurones arise by the mitotic division of migrant cells either before or after they have become incorporated in the primordia of the sympathetic nervous system. According to this interpretation, the sympathetic system is entirely homologous with the other functional divisions of the nervous system.

\section{SUMMARY}

The primordia of the sympathetic trunks and the prevertebral plexuses arise from cells of cerebrospinal origin which advance peripherally both along the dorsal and ventral roots of the spinal nerves.

The vagal sympathetic plexuses, viz., the pulmonary, the cardiac, and the enteric plexuses, except in the aboral portions of the digestive tube, arise from cells of cerebrospinal origin which advance peripherally along the vagi. In the more distal portions of the digestive tube the enteric plexuses arise from cells which are derived from the sympathetic supply in the lower trunk region.

The majority of the cells which constitute the primordium of the ciliary ganglion are derived from the semilunar ganglion via the ophthalmic nerve. Relatively few cells are contributed via the oculomotor nerve.

The cells which enter the primordium of the sphenopalatine ganglion earliest advance peripherally along the greater superficial petrosal nerve. The majority of the cells which enter the primordium of this ganglion are derived from the semilunar ganglion via the maxillary nerve and its rami.

The primordium of the otic ganglion arises at the growing extremity of the lesser superficial petrosal nerve as an aggregate of cells which advance primarily from the petrosal ganglion. The otic ganglion also receives cells of trigeminal origin via the mandibular nerve and its rami.

The submaxillary and sublingual ganglia arise on the lingual nerve primarily from cells of trigeminal origin. They probably receive some cells of facial origin via the chorda tympani. 
The smaller sympathetic ganglia associated with the rami of the glossopharyngeal nerve in the posterior portion of the tongue arise from cells which advance into the tongue along the glossopharyngeal fibers.

The cells which give rise to sympathetic neurones are derived both from the cerebrospinal ganglia and the neural tube. Not all of these cells actually migrate as such from the cerebrospinal nervous system. Many of them arise by the mitotic division of migrant cells along the paths of migration and in the primordia of the sympathetic nervous system.

\section{LITERATURE CITED}

Abes, W. 1910 The development of the autonomic nervous mechanism of the alimentary canal of the bird. Proc. Roy. Soc. of Edinburgh, vol. 30, pt. 4, pp. 327-347.

1912 Further observations on the development of the sympathetic nervous system in the chick. Jour. Anat. and Physiol., vol. 47, pp. $35-72$.

Batfotr, F. M. 1877 The development of elasmobranch fishes. Development of the spinal nerves and the sympathetic nervous system. Jour. Anat. and Physiol., vol. 11.

Béraneck, E. 1884 Recherches sur le développement des nerfs craniens chez le lezards. Recueil zool. suisse, ser. 1, T. 1, pp. 519-693.

Broman, I. 1911 Entwickelung des sympathischen Nervensystems. Normale und abnormale Entwickelung des Menschen. Wiesbaden, 1911, S. 712-717.

CAJaL, S. R. Y 1908 Nouvelles observations sur l'evolution des neuroblastes, avec quelques remarques sur l'hypothese neurogenetique de HensenHeld. Anat. Anz., Bd. 22, s. 1-25 and 65-78.

Camus, R. 1912 Ueber die Entwickelung des sympathischen Nervensystems beim Frosch. Arch. f. mikr. Anat., Bd. 81, Abt. 1, S. 1-52.

Carpenter, F. W. 1906 The development of the oculomotor nerve, the ciliary ganglion and the abducent nerve in the chick. Bull. Mus. Comp. Zool. Harvard College, vol. 48, pp. 141-228.

Chiarugi, G. 1894 Lo sviluppo dei nervi oculomotore e trigemello. Nota preliminare. Monit. zool. ital., anno 5, no. 12, pp. 275-280.

1897 Contribuzioni allo studio dello sviluppo dei nervi encefalici nei mammiferi in confronto con altri vertebrati. IV. Sviluppo dei nervi oculomotore e trigemello. Pubbl. instit. di studi sup. prat. e di prefez. in Firenze, Sez. med. e chir.

Ewart, J. C. 1890 On the development of the ciliary or motor oculi ganglion. Proc. Roy. Soc. London, vol. 47, pp. 287-290.

Froriep, A. 1907 Die Entwickelung und Bau des autonomen Nervensystems. Medizinisch-naturwiss. Archiv, Bd. 1, S. 301-321. 
Ganfini, C. 1911 Lo sviluppo del sistema nervoso simpatico in alcuni Pesci. Archivio Italiano di Anat. e di Embriol., T. 10, pp. 574-645.

1914 Lo sviluppo del sistema nervoso simpatico in alcuni rettilio. Ibid., T. 13, pp. 492-538.

1916 Lo sviluppo del sistema nervosọ simpatico negli uccelli. Ibid., T. 15, pp. 91-138.

1917 Lo sviluppo del sistema nervoso simpatico nei Mammiferi. Ibid., T. 16, pp. 43-125.

1918 Su alcuni gangli del III, V, e tronco anteriore del VII in embrioni di Amnioti. Ibid., T. 16, pp. 342-381.

Harrison, R. G. 1901 The histogenesis of the peripheral nervous system in Salmo salar. Biol. Bull., vol. 2.

1904 Neue Versuche und Beobachtungen über die Entwickelung der peripheren Nerven der Wirbeltiere. Sitzungsber. d. Niederrhein. Ges. f. Nat. u. Heilkunde zu Bonn.

1906 Further experiments on the development of peripheral nerves. Am. Jour. Anat., vol. 5, pp. 121-131.

HeLd, H. 1909 Die Entstehung der sympathischen nerven. Die Entwickelung des Nervengewebes bei den Wirbeltieren, Leipzig, 1909, S. 212-241.

Hrs, W., JR. 1891 Die Entwickelung des Herznervensystems bei Wirbelthieren. Abhandl. Math.-physischen Classe d. Königl. Sächs. Ges. d. Wiss., Bd. 8, Leipzig.

1897 Ueber die Entwickelung des Bauchsympathicus bein Hühnchen und Menschen. Arch. Anat. u. Entwg., Suppl.

Конл, А. 1905 Ueber die Entwickelung des peripheren Nervensystems. Verhdl. d. anat. Ges., Jena.

1907 Ueber die Entwickelung des sympathischen Nervensystems der Säugetiere. Arch. f. mikr. Anat., Bd. 70, S. 266-317.

KonTz, A. 1909 a A contribution to the histogenesis of the sympathetic nervous system. Anat. Rec., vol. 3, pp. 158-165.

$1909 \mathrm{~b}$ The rôle of the vagi in the development of the sympathetic nervous system. Anat. Anz., Bd. 35, S. 381-390.

1910 a The development of the sympathetic nervous system in mammals. Jour. Comp. Neur., vol. 20, pp. 211-258.

$1910 \mathrm{~b}$ The development of the sympathetic nervous system in birds. Jour. Comp. Neur., vol. 20, pp. 284-308.

1911 a The development of the sympathetic nervous system in certain fishes. Jour. Comp. Neur., vol. 21, pp. 177-214.

$1911 \mathrm{~b}$ The development of the sympathetic nervous system in turtles. Am. Jour. Anat., vol. 11, pp. 279-312.

1911 e The evolution of the sympathetic nervous system in vertebrates. Jour. Comp. Neur., vol. 21, pp. 215-236.

$1911 \mathrm{~d}$ The development of the sympathetic nervous system in the Amphibia. Jour. Comp. Neur., vol. 21, pp. 397-416.

1913 The development of the cranial sympathetic ganglia in the pig. Jour. Comp. Neur., vol. 23, pp. 71-96.

1914 Further studies on the development of the cranial sympathetic ganglia. Jour. Comp. Neur., vol. 24, pp. 235-267. 
Marcus, H. 1909 Ueber den Sympathicus. Sitzungsbericht d. Ges. f. Morph. u. Physiol. in München.

Neal, H. V. 1914 The morphology of the eye-muscle nerves. Jour. Morph., vol. 25, pp. 1-187.

Neumayer, L. 1906 Histogenese und Morphogenese des peripheren Nervensystems, der Spinalganglien und des Nervus Sympathicus. Handbuch der vergl. u. experiment. Entwickelungslehre der Wirbeltiere, Bd. 2, S. 513-626.

ÓNodi, A. D. 1886 Ueber die Entwickelung des sympathischen Nervensystems. Zweiter Theil. Arch. f. mikr. Anat., Bd. 181, S. 159-186.

Reuter, K. 1897 Ueber die Entwickelung der Augenmuskulatur beim Schwein. Anat. Hefte, Bd. 9, S. 365-387.

Rex, H. 1900 Zur Entwickelung der Augenmuskeln der Ente. Arch. f. mikr. Anat., Bd. 57, S. 229-271.

Schaper, A. 1897 Die frühsten Differenzierungsvorgänge im Zentralnervensystem. Kritische Studie und Versuch einer Geschichte der Entwickelung nervöser Substanz. Arch. f. Entw.-Mech., Bd. 5, S. 81-132.

StEWART, F. W. 1920 The development of the cranial sympathetic ganglia in the rat. Jour. Comp. Neur., vol. 31, pp. 163-217.

Streeter, G. L. 1912 The development of the nervous system. IV. Sympathetic nervous system. Human Embryology, Keibel and Mall, vol. 2, pp. 144-156. 
PLATES 


\section{PLATE 1}

\section{EXPLANATION OF FIGURES}

13 Human embryo, $7 \mathrm{~mm}$. in length, $617-13-1-3 \times 315$. Transverse section through lower thoracic region showing spinal nerve and sympathetic trunk. $a$, aorta; $c$, communicating ramus; $s p$, spinal nerve; $S y$, sympathetic trunk.

14 Human embryo, $9 \mathrm{~mm}$. in length, $721-13-1-3 \times 335$. Transverse section showing ventral root of spinal nerve with migrant medullary cells (cor).

15 Human embryo, $14 \mathrm{~mm}$. in length, 511-9-1-2×160. Sagittal section showing vagus branch to bulbar region of heart with aggregates of cells which become incorporated in cardiac plexus $(c p)$. 

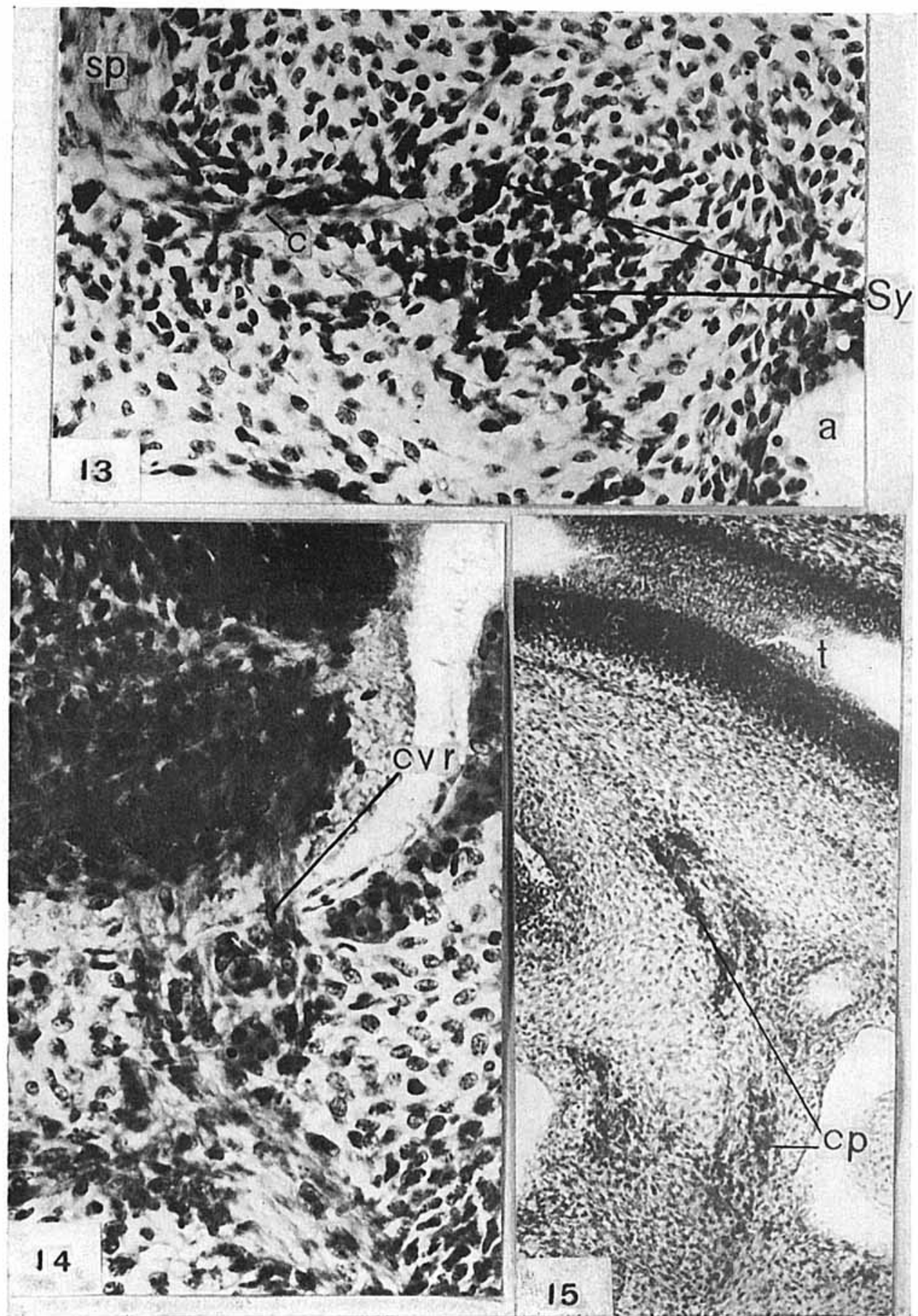


\section{PLATE 2}

\section{EXPLANATION OF FIGURES}

16 Human embryo, $10.1 \mathrm{~mm}$. in length, 623-16-3-7×160. Transverse section through abdominal region showing primordia of sympathetic trunks and prevertebral plexuses. $a$, aorta; $p v$, prevertebral plexuses; $S y$, sympathetic trunk.

17 Human embryo, $10.1 \mathrm{~mm}$. in length, 623-15-2-2×160. Transverse section through upper abdominal region showing primordia of sympathetic trunks and prevertebral plexuses. $a$, aorta; $p v$, prevertebral plexuses; $S y$, sympathetic trunk. 


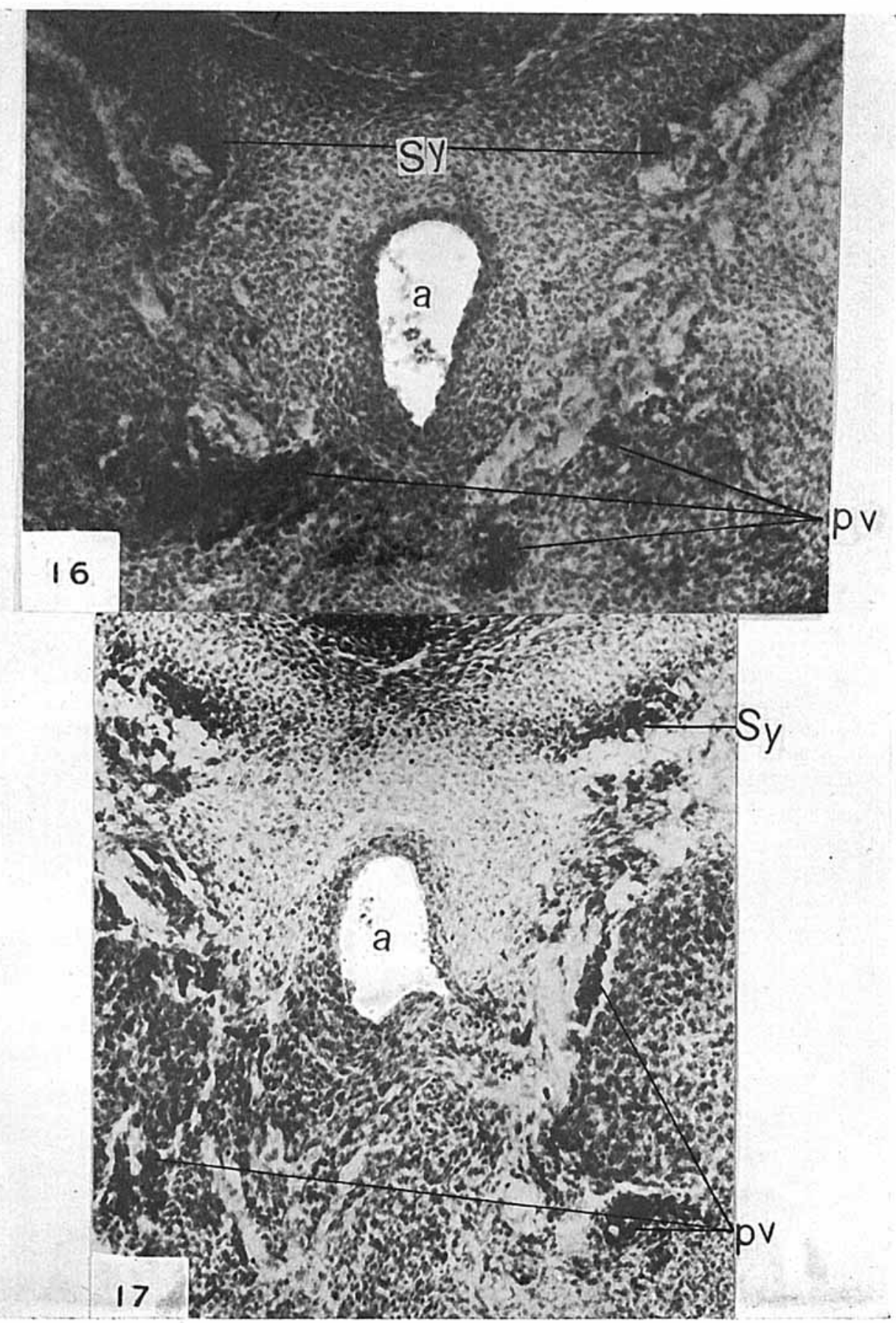




\section{PLATE 3}

EXPLANATION OF FIGURES

18 Human embryo, $10.1 \mathrm{~mm}$. in length, $623-10-2-4 \times 240$. Transverse section through oesophagus showing vagus trunks and oesophageal plexus, oep, cell aggregates in oesophageal plexus; $v$, vagus trunks.

19 Human embryo, $10.1 \mathrm{~mm}$. in length, 623-13-2-2-2×240. Transverse section through oesophagus just above upper level of heart showing oesophageal plexus. oep, eell aggregates in oesophageal plexus; $v b$, vagus branches.

20 Human embryo, $10.1 \mathrm{~mm}$. in length, 623-11-2-4×240. Transverse section through roots of lungs showing primordia of pulmonary plexuses. $p p$, cell aggregates in pulmonary plexuses; $v b$, vagus branches. 

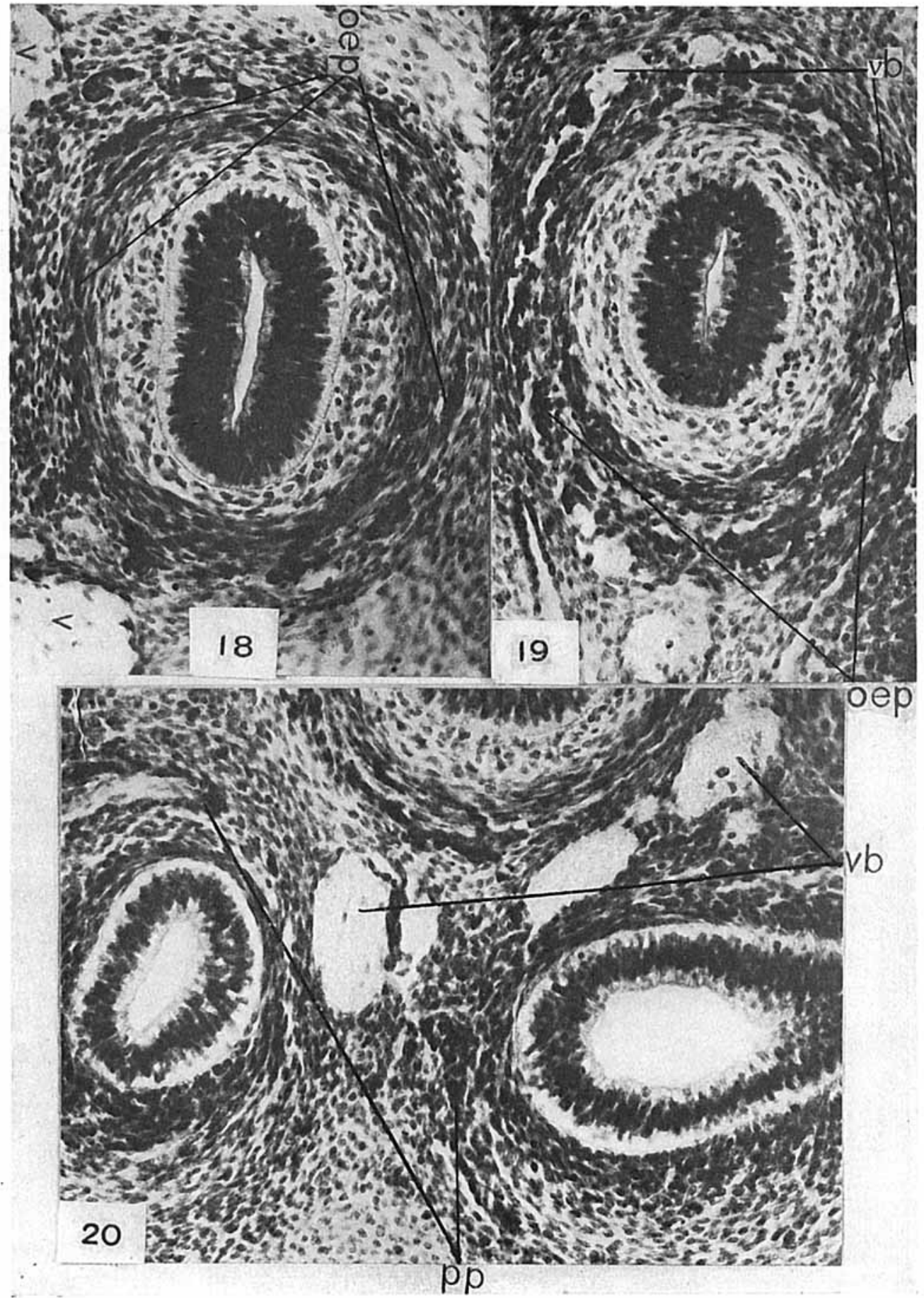


\section{PIATE 4}

\section{EXPLANATION OF FIGURES}

21 Human embryo, $14 \mathrm{~mm}$. in length, $511-12-2-2 \times 160$. Sagittal section through primordium of ciliary ganglion ( $\mathrm{g} g)$. $O C N$, oculomotor nerve; $O p$, ophthalmic nerve.

22 Human embryo, $13 \mathrm{~mm}$. in length, 485-8-2-2×335. Section showing apparent cellular continuity between semilunar and otic ganglia. Man, mandibular nerve; og, otic ganglion; $S G$, semilunar ganglion.

23 Human embryo, $14.6 \mathrm{~mm}$. in length, 1919-11-2-2×160. Coronal seetion showing maxillary ramus $(m r)$ leading into primordium of sphenopalatine ganglion ( $s p g)$. $g s p$, nerve of the pterygoid canal which includes the fibers of the greater superficial petrosal nerve; $M$, maxillary nerve; $S G$, semilunar ganglion. 


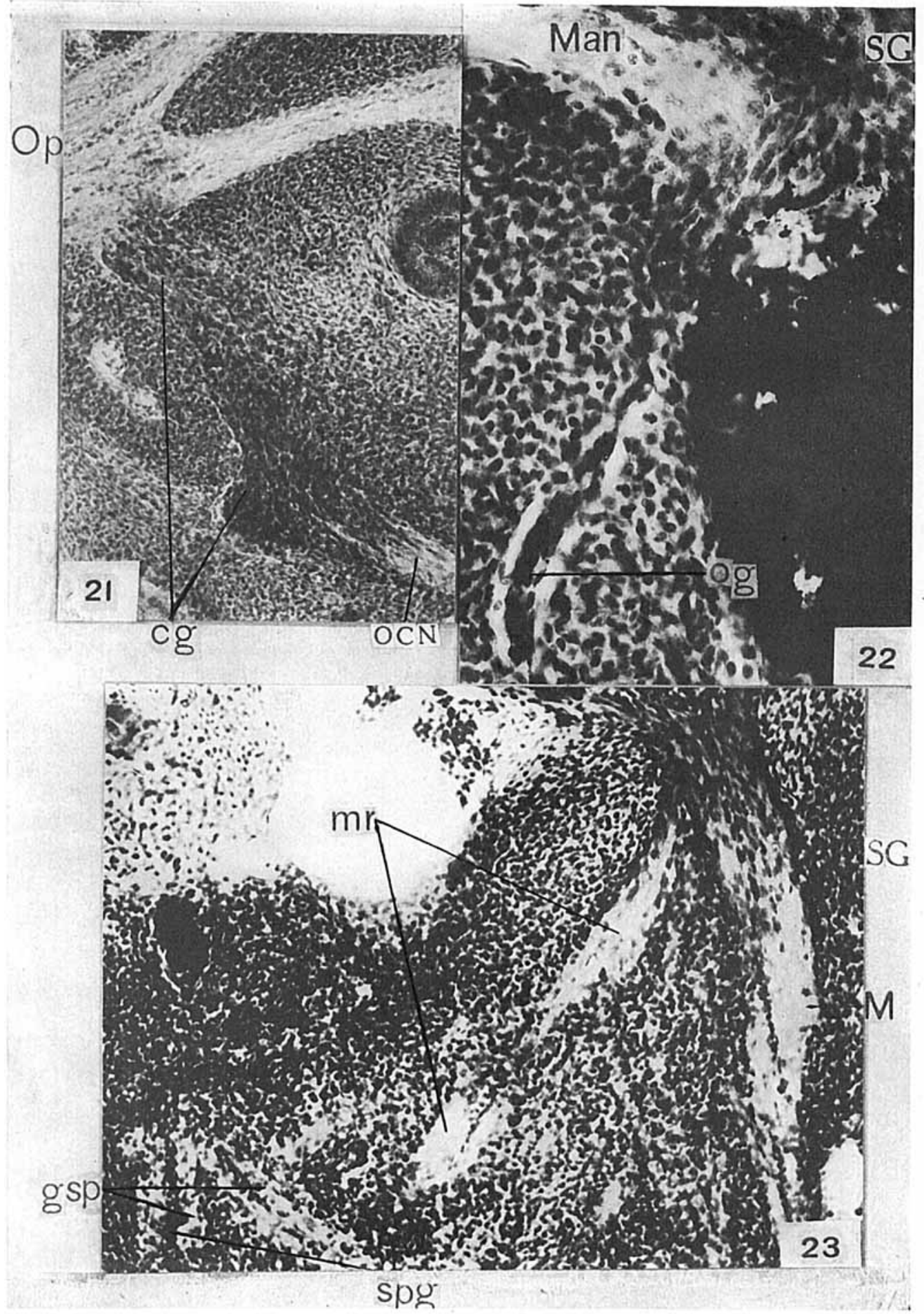


PLATE 5

EXPLANATION OF FIGURES

24 Human embryo, $20 \mathrm{~mm}$. in length, 462-15-1-1×335. Section cutting maxillary nerve $(M)$ transversely at level of sphenopalatine ganglion (spg), showing maxillary ramus $(m r)$ into the latter.

25 Human embryo, $20 \mathrm{~mm}$. in length, $462-15-1-1 \times 160$. Section showing maxillary ramus $(\mathrm{mr})$ and nerve of the pterygoid canal entering sphenopalatine ganglion $(s p g)$. GSP, nerve of the pterygoid canal which includes the fibers of the greater superficial petrosal nerve.

26 Human embryo, $21 \mathrm{~mm}$. in length, 460-16-2-2×130. Section showing maxillary ramus $(\mathrm{mr})$ and nerve of the petrygoid canal (GSP) entering sphenopalatine ganglion. 

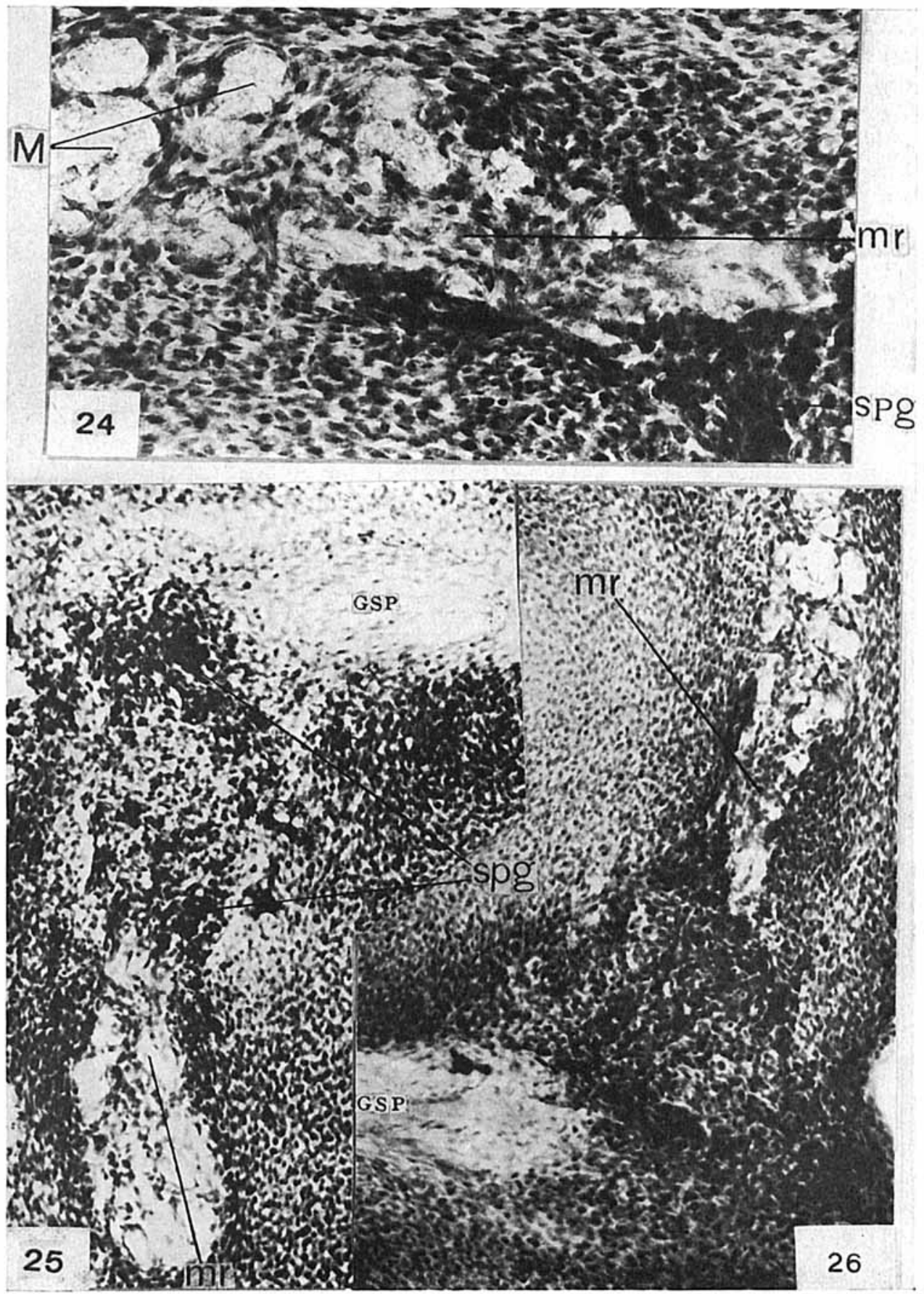
PLAT'E 6

EXPLANATION OF FIGURES

27 Human embryo, $20 \mathrm{~mm}$. in length, 462-14-2-3×335. Section through mandibular nerve (Man) and ramus (Mnr) to otic ganglion $(O G)$.

28 Human embryo, $21 \mathrm{~mm}$. in Iength, 460-16-1-2×160. Section eutting mandibular nerve (Man) transversely at level of otic ganglion $(O G)$. 
ALBERT KUNTZ
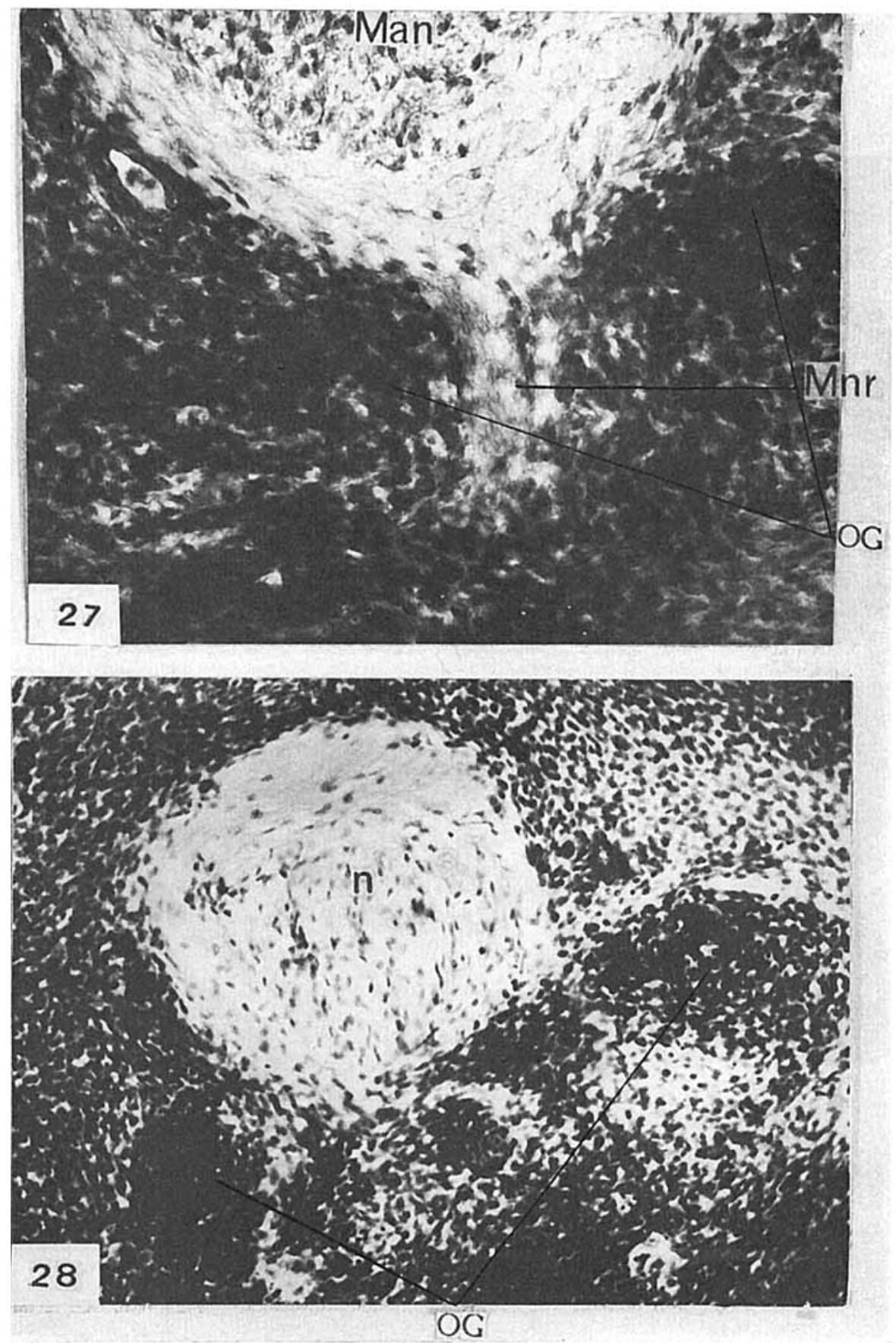
PLATE 7

EXPLANATION OF FIGURES

29 Human embryo, $14 \mathrm{~mm}$. in length, $144-5-2-2 \times 240$. Sagittal section showing cellular ramus $(C S)$ connecting otic $(O G)$ and sphenopalatine $(S P G)$ ganglia.

30 Human embryo, $14.5 \mathrm{~mm}$. in length, $1267-8-2-3 \times 315$. Section through motor root of trigeminal nerve (MRV) showing migrant medullary cells.

31 Human embryo, $13 \mathrm{~mm}$. in length, 485-13-8--3×120. Section showing primordium of submaxillary ganglion $(S M G)$. lin, lingual nerve. 


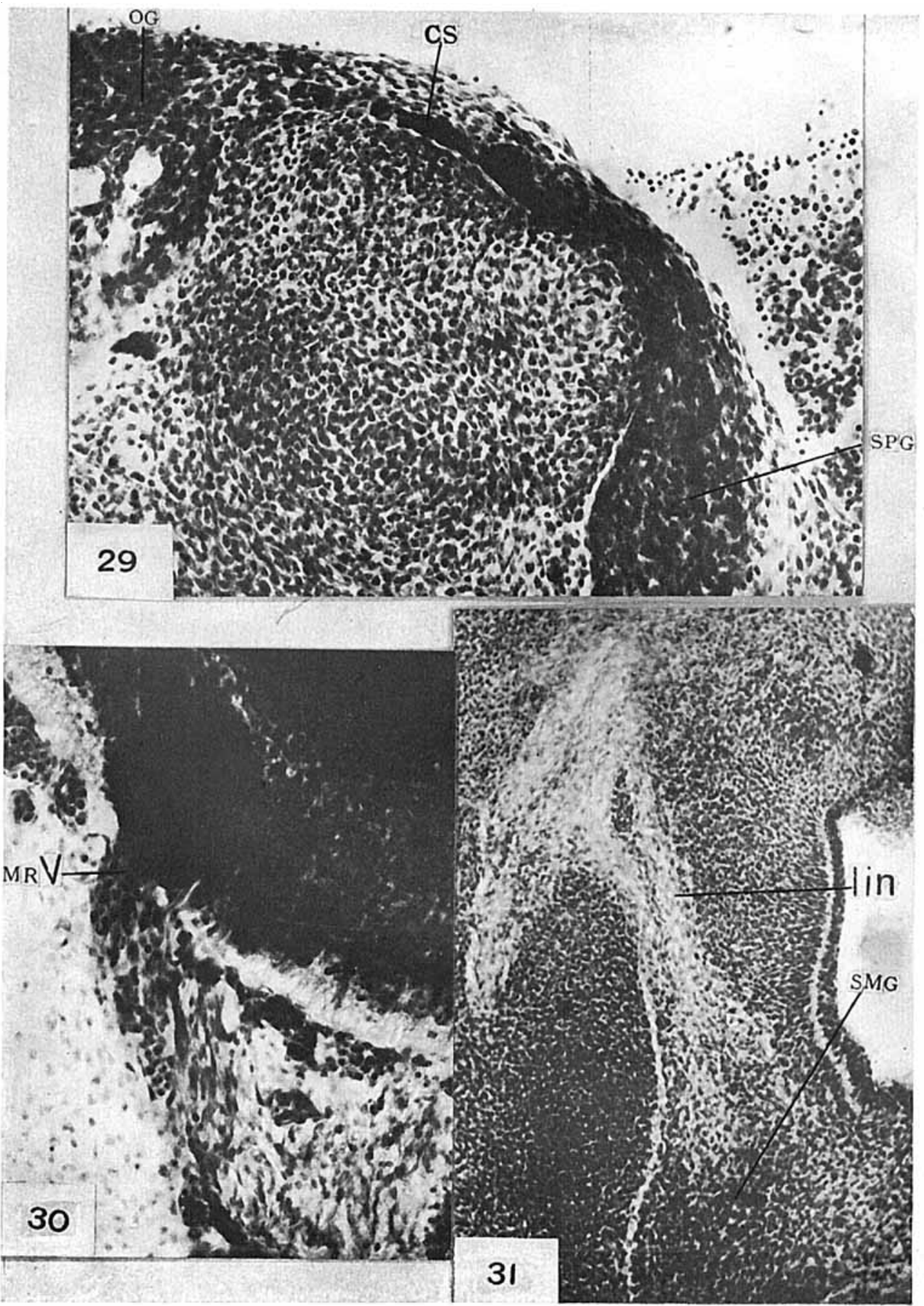

